Open Access

\title{
Towards a typology of university technology transfer organizations in China: evidences from Tsinghua University
}

\author{
Han Zhang ${ }^{1}$, Yuzhuo Cai ${ }^{2 *}$ and Zhengfeng $\mathrm{Li}^{3}$
}

\footnotetext{
* Correspondence: yuzhuo.cai@uta.fi ${ }^{2}$ School of Management, University of Tampere, Tampere, Finland Full list of author information is available at the end of the article
}

\begin{abstract}
This paper argues that failure to deeply understand various existing organizations of university-industry technology transfer in China impedes the progress of both practice and research on technology transfer between university and industry in that country. In response, it attempts to categorize different types of university technology transfer organizations in China in over a 30-year time span and analyze the relations between these organizations. In so doing, Tsinghua University is taken as an example for analysis, because technology transfer at Tsinghua University can be seen as a microcosm of university-industry technology transfer in China with pioneer practices and successful experience to be followed by other universities in China. The analysis is guided by an analytical framework, constructed by integrating the insights from relevant literature. The framework distinguishes between different forms of university technology transfer organizations by focusing on six dimensions of the organizational characteristics. After identifying eight types of university technology transfer organizations in Tsinghua University with detailed descriptions of their respective organizational characteristics, the paper further groups them into a four-category typology. Besides its contribution in constructing a framework to understand university technology transfer organizations in the Chinese context, the paper also solicits suggestions for Chinese and international stakeholders who may potentially cooperate with Chinese research universities in research, development, and innovation.
\end{abstract}

Keywords: Technology transfer, Innovation, University and industry interaction, Tsinghua University, China 
摘 要

本文认为, 缺乏对中国大学-产业技术转移组织存在类型的深入研究, 制约了中国 大学与产业技术转移研究和实践。作为回应, 该文试图对30多年以来中国不同类 型的大学技术转移组进行分类并分析这些这些组织之间的关系。具体的分析是 以清华大学为例, 这样的选择是因为清华大学的技术转移可以看作是中国大学产业技术转移发展的一个缩影, 清华作为大学-产业技术转移的先行者积累了很 多成功的经验，也成为其他学校效仿的一个样板。本研究使用的分析框架，是在 整合相关文献的基础上构建的，该框架通过关注组织特征的六个维度来区分不同 形式的大学技术转移组织。在辨认了清华大学八种类型的大学技术转移组织并 详细描述了每种类型的组织特征后，本文进一步将它们分成四类。除了为研究中 国背景下的大学技术转移组织构建一个分析框架, 本研究还为可能与中国研究型 大学合作的国内外利益相关和提供了有益的建议。

关键词: 技术转移, 创新, 大学-产业互动, 清华大学, 中国

\section{Résumé}

Cet article soutient que l'impossibilité de comprendre de manière exhaustive les formes organisationnelles existantes de transfert de technologie entre université et industrie (UITT) en Chine plombe les avancées à la fois de la pratique et de la recherche en matière de transfert de technologie entre l'université et l'industrie dans ce pays. En réponse, une tentative de catégorisation des différents types d'organisations universitaires de transfert de technologie (UTTO) est proposée. L'évolution de ces organisations visait à répondre à la demande d'innovation en Chine à différentes étapes. Pour mieux comprendre la typologie des UTTO, I'Université de Tsinghua est prise comme exemple, le transfert de technologie à I'Université Tsinghua pouvant être considéré comme un microcosme dans le domaine en Chine, avec des pratiques pionnières en matière d'organisation de I'UITT et une expérience réussie à suivre par les universités en Chine. Ce faisant, nous intégrons les connaissances tirées de la littérature internationale pertinente pour construire un cadre analytique mettant l'accent sur six dimensions des caractéristiques organisationnelles des UTTO afin de distinguer les modèles. Outre l'identification et la description détaillée des caractéristiques organisationnelles respectives de huit types d'UTTO à I'Université de Tsinghua, le document contribue également à la science en améliorant les outils analytiques existants permettant de catégoriser et d'examiner les caractéristiques organisationnelles des UTTO. Sur la base des résultats de nos recherches, nous sollicitons également des suggestions d'acteurs chinois et internationaux susceptibles de coopérer avec des universités chinoises en matière de recherche et développement et de transfert de technologie.

Mots-clés: transfert de technologie, innovation, interaction université-industrie, Université de Tsinghua, Chine

\section{Resumo}

Este artigo argumenta que a falha em entender profundamente várias organizações de transferência de tecnologia entre universidade e indústria existentes na China impede o progresso de prática e pesquisa de transferência de tecnologia entre universidade e indústria no país. Em resposta, este artigo propõe-se a categorizar diferentes tipos de organizações de transferência de tecnologia universitária na China em um período de 30 anos e a analisar as relações entre estas organizações. Desta (Continued on next page) 
(Continued from previous page)

forma a Universidade de Tsinghua é usada como exemplo para a análise, uma vez que, a transferência de tecnologia na Universidade de Tsinghua pode ser vista como um microcosmo de transferência de tecnologia universidade-indústria na China com práticas pioneiras e experiências bem sucedidas para serem seguidas por outras universidades na China. A análise é guiada por um framework analítico construído pela integração dos insights de literaturas relevantes. $\bigcirc$ framework distingue entre diferentes formas de organizações de transferência de tecnologia universitária, concentrando-se em seis dimensões das características organizacionais. Depois de identificar oito tipos de organizações universitárias de transferência de tecnologia na Universidade de Tsinghua, com descrições detalhadas de suas respectivas características organizacionais, o artigo as agrupa em uma tipologia de quatro categorias. Além de sua contribuição na construção de um framework para entender as organizações universitárias de transferência de tecnologia no contexto chinês, o documento também solicita sugestões para stakeholders chineses e internacionais que possam potencialmente cooperar com universidades chinesas de pesquisa nos campos de pesquisa, desenvolvimento e inovação.

Palavras-chave: transferência de tecnologia, inovação, interação universidadeindústria, universidade de Tsinghua, China

\section{Аннотация}

В настоящей статье обсуждаются сложности формирования объективной оценки существующих организационных форм технологического трансфера УниверситетПромышленность (UITT) в Китае, что препятствует прогрессу в практике и исследовании вопросов технологического трансфера между университетами и промышленностью в этой стране. Применительно к данной задаче была сделана попытка категоризации различных типов университетских организаций, осуществляющих технологический трансфер (UTTOs). Эволюция данных организаций была вызвана необходимостью удовлетворения потребности в инновациях в Китае в различные периоды времени. Для формирования типологии UTTOs был рассмотрен пример Университета Цинхуа, поскольку организация технологического трансфера здесь может быть использована как миниатюра в рамках Китая, где реализованы передовые практики UITT, а его успешный опыт использован другими китайскими университетами. Решая данную задачу, мы объединили данные, представленные в релевантных международных публикациях, для того, чтобы сформировать аналитическую модель с шестью измерениями организационных характеристик UTTOs и выявить различия между моделями. Помимо идентификации восьми типов UTTOS в Университете Цинхуа с детальным описанием их организационных характеристик, в статье также представлены данные по совершенствованию аналитических инструментов для категоризации и изучения организационных характеристик UTTOs. Принимая во внимание результаты исследования, мы хотим привлечь к сотрудничеству китайских и международных партнеров, которые могут быть потенциально заинтересованы в сотрудничестве с китайскими исследовательскими университетами в сфере исследований и разработок (R\&D) и трансфера технологий.

ключевые слова: Трансфер Технологий, инновации, взаимодействие университета и промышленности, Университет Цинхуа, Китай 


\section{Resumen}

Para mejorar la transferencia de tecnología entre universidades e industria (UITT), debemos primero comprender de manera integral la organización de este proceso. Aquí presentamos una tipología de oficinas universitarias de transferencia de tecnología (UTTO). Debemos recalcar que estas organizaciones no son estáticas en el tiempo, sino han evolucionado para satisfacer la demanda de innovación en China en diferentes periodos. Para explicar nuestra tipología, tomamos como ejemplo la Universidad de Tsinghua, ya que su programa se puede considerar un microcosmos de la transferencia de tecnología en China y también es un programa líder entre otras universidades debido a sus prácticas pioneras y su experiencia exitosa. Hemos sintetizado la literatura para identificar seis dimensiones de las UTTOs que dan lugar a nuestra tipología. Usando este marco analítico, hemos identificado ocho tipos de UTTO en la Universidad de Tsinghua y ofrecemos descripciones detalladas de sus respectivas características organizativas. Este marco analítico es nuestra contribución al estudio de UTTO en sus diferentes tipos, formas de organización, y operación.

Esperamos que nuestra investigación se lea como una invitación abierta a organizaciones chinas e internacionales dedicadas al estudio de investigación y desarrollo y transferencia de tecnología en China.

Palabras Clave: Transferencia de tecnología, innovación, interacción universidadindustria, Universidad de Tsinghua, China

\section{Multilingual abstract}

Please see Additional file 1 for translation of the abstract into Arabic.

A few highlights of the paper are provided as follows:

- The study first time identifies a full spectrum of models of university technology transfer organizations (UTTOs) as well as their interrelations in Tsinghua University in China and further proposes a typology of UTTOs in China.

- International UTTO models are used as a benchmark to identify and compare the models and characteristics of UTTOs in China.

- The evolution process of the development of different types of UTTOs since the 1980s is provided.

- The characteristics of each type of UTTOs are demonstrated by using Tsinghua University as an example.

- Policy and managerial recommendations are solicited.

\section{Introduction}

Since the passage of the Bayh-Dole Act in the 1980s, the role of university-industry technology transfers for enhancing national innovation capacity has been commonly acknowledged worldwide (Weckowska 2015; Kalar and Antoncic 2015; Cesaroni and Piccaluga 2015). Activities concerning technology transfer have become a main area of innovation in higher education (Cai 2017). The term university-industry technology transfer is often used to refer to the process whereby some invention or intellectual property from academic research is licensed or conveyed through user rights to a 
for-profit entity and eventually commercialized (Friedman and Silberman 2003). In this definition, the technology is mainly concerned with inventions or IP, and the transfer is about how the technology is licensed or conveyed through user rights to a for-profit entity and eventually being commercialized (Teng 2010). Successful technology transfer depends not only on the capacity of the creator of intellectual property (IP) (Wright et al. 2004), but also on efficient ways of organizing the process of technology transfer (Heinzl et al. 2013). In fact, university-industry technology transfer activities are often conducted in technology transfer organizations, which act as intermediaries between the academics as the producers of new knowledge and technology and the firms or other potential investors who are interested in acquiring the technological assets (Franzoni 2007). In this light, how university-industry technology transfer is organized is mainly reflected in both the functions and structures of university technology transfer organizations. Here, university technology transfer organizations are defined as those organizations performing the role of university-industry technology transfer but with strong organizational ties to universities, in terms of, e.g., administration and ownership.

Following the successful examples in the USA, in Europe, the 1980s and 1990s saw the creation of a large number of organizations to facilitate knowledge (or technology) transfer for economic development (Geuna and Muscio 2009). Such a phenomenon can also be witnessed in China. The importance of university-industry technology transfer has been accentuated in China's recent strategy for independent innovation (Huang et al. 2013), and university-industry technology transfer has become an important source of industry innovation (Cai et al. 2015; Orcutt and Shen 2010; Tang 2009; Cai and Liu 2015; Wu and Zhou 2012). In the past 15 years, Chinese universities have greatly improved their ability to create and diffuse commercially useful technology (Orcutt and Shen 2010; Cai et al. 2015). As one of the world's largest academic research performers, far less is known about the ways how the research outputs of universities are transferred and organized in China.

The university serving society's needs was a governmental mandate in a centrally planned system (Cai 2004). As such, there was little transfer of research results from either research institutions or universities to industrial production before the end of 1970s (Chen and Kenney 2007). University-industry technology transfer practices were mainly "technology service," "technology docking," or in the form of university-run factories; the research outcomes were not to be sold as the commodity in the market. The initial motivations for universities' engagement in technology transfer without economic incentives lied in their belief that solving technological problems for factories could enhance the university's image and prestige.

The real university-industry technology transfer developments started to take place in the 1980s and 1990s (Cai et al. 2015), concurrently with similar phenomena in many Western countries. In that period, a series of laws and policies was introduced as a call for revitalizing the nation through science and education, alongside the social economic system being transformed to a market-oriented system (Cai and Yan 2017). Consequently, universities have become central players in both national and regional innovation system development in China (Cai 2018).

In 2002, the Ministry of Finance and the Ministry of Science and Technology co-issued the Several Regulations Concerning the Intellectual Property Management of 
State Scientific and Research Program Results (hereafter Regulations) to improve the process of technology licensing or transfer (Lin et al. 2011). Many scholars regarded the Regulations as the Chinese version of the Bayh-Dole Act, and its positive impact on facilitating university-industry technology transfer is apparent (Hong 2008; Tang 2009). The further legislation granting universities intellectual property rights to government-funded inventions was the 2007 Law of the People's Republic of China on Science and Technology Progress, which upgrades the provisions of the Regulations with respect to intellectual property ownership to the level of a national law. The Law grants intellectual property ownership to those undertaking projects sponsored by governmental funding (Lin et al. 2011). These efforts have ushered the university technology transfer into a new and fast growing stage.

In addition to the policy context, when analyzing technology transfer and university technology transfer organizations in China, we must be aware of the wider social institutional context fostering innovation as well as interactions between key actors in innovation systems (Cai 2015). The unique institutional context in China may shape innovation system development in a different way from that seen in the West (Cai 2014) and also determine the way of organizing technology transfer.

Since the 1980s, a variety of university technology transfer organizations have been established in China, being used as instruments to facilitate technology transfer between university and industry. China is still in the process of exploring optimal models of university technology transfer organizations (Cai et al. 2015). To identify the most effective models for organizing universities' technology transfer, we must first know what types of university technology transfer organizations exist and how they are functioning. However, as revealed in details in the "Literature Review" section, there is a research gap on a holistic and comprehensive understanding of existing organizational forms of university-industry technology transfer in China. This has not only become an obstacle to policy-makers seeking optimal models of university-industry technology transfer, but also hampers researchers to understand and compare various studies on university technology transfer organizations for knowledge advancement. Moreover, there is a lack of understanding of why certain organizations emerge in a specific historical occasion. To fill the gaps, this paper poses the following research questions: What are the types of university technology transfer organizations in China since 1980s? And what are the organizational characteristics of each type and how different types of university technology transfer organizations are related to each other? To answer these questions, we take Tsinghua University as an example to illustrate the evolution of various university technology transfer organizations as well as their characteristics. Tsinghua University as the leading science and technology university of China was a pioneer in the commercialization of its scientific achievements.

\section{Literature review}

In this section, we will first clarify the main concepts used in the study, namely university-industry technology transfer and university technology transfer 
organizations. It is followed by a review of the literature that distinguishes different types of technology transfer organizations. Finally, we review relevant studies on university technology transfer organizations in China.

\section{Definition of university-industry technology transfer and university technology transfer organizations}

The university's contribution to the industrial world is not simply about patents and technology for developing new products, but also new ways of organizing things through entrepreneurial support and consulting (Poglajen 2012). In this light, we follow Heinzl et al. (2013), who define university-industry technology transfer as "the process of moving technology from an institution of the science base (e.g. a higher education institution) to an industrial organization, which successfully commercializes the technology through the implementation of new processes, the development and launch of new products or the facilitation of a successful and innovative organizational change." The technology transfer between academia and industry often occurs through technology transfer organizations.

Technology transfer organizations include both universities' internal offices for technology transfer and other kinds of agencies, such as industrial liaison offices, incubators, campus ventures, science parks, university-run enterprises, and spin-offs. Indeed, technology transfer involves wide ranges of organizations in different sectors. This study confines its focus to university technology transfer organizations, referring to those organizations performing the role of university-industry technology transfer but with strong organizational ties to universities. They may be a university's internal units, business entities owned or partially owned by the university as well as research and development $(R \& D)$ centers and incubators run jointly by universities and regional governments.

\section{Major studies on models and organizational characteristics of university technology transfer organizations}

Knowledge transfer has become a strategic issue for universities; many studies have attempted to understand the organizational characteristics of university technology transfer organizations (Markman et al. 2005; Siegel et al. 2003a; Siegel et al. 2003b; Link and Siegel 2005; Friedman and Silberman 2003), and only very few try to distinguish between different types of university technology transfer organizations or present key parameters for observation and comparison.

Drawing on and synthesizing organizational theories (Chandler 1962; Drucker 1973; Williamson 1975), Bercovitz et al. (2001) argued the university technology transfer organizations' incentives, information processing, and coordination capability differ according to their structures. They first developed a typology of university technology transfer organizations: (1) Unitary Form (U-Form), functionally departmentalized structure with centralized decision-making and coordination responsibilities; (2) Multidivisional structure (M-Form), decomposed into semi-autonomous operating divisions; (3) Holding Company (H-Form), a divisional approach but the decision-making body is weaker than that in the M-form; and (4) The Matrix Structure (the MX-Form), operates simultaneously 
with both a functional and product hierarchy; thus, the decision-makers are at the intersection of two organizations. They proposed that the semi-centralized university technology transfer organizations would be the most efficient structures, managed by a central office with highly decisional power, coordination, and information processing capabilities.

Brescia et al. (2016) found university technology transfer organizations can grow both internally and externally to create new organizational structure; they identified three basic models, internal unit, the external unit, and the combination ones managed by several company/office, and the collaborations among different university technology transfer organizations are of great importance to configure the relationships, to affect their own structures and achieve external growth.

Following the new institutional theory framework (DiMaggio and Powell 1983), Poglajen (2012) proposed a six-dimension framework (see Table 1) to explain how new institutionalism incorporates historical experiences into a university technology transfer organization's rules and organizing logics and why certain forms of university-industry technology transfer organizations are selected.

In a similar effort, Schoen et al. (2014) further provides a new typology of organizational models, according to the structural variable, and four types of university technology transfer organizations are identified when applied to 16 case studies of European countries (in Table 2). Comparing the typology dimensions to that in Poglajen (2012)'s, Schoen et al. (2014) add up a new dimension, the concept of degree of discipline specialization; it concerns whether technology transfer activities focus on one specific academic discipline or not, and it occurs on either the departmental level or the institutional level involving all departments. Although both Poglajen (2012) and Schoen et al. (2014) use the concept of specialization, they have different ways of categorizing the tasks. Different to Poglajen (2012) as indicated in Table 1, Schoen et al. (2014)'s classification of task specialization is described as follows: (1) A fully integrated technology transfer organization is responsible for all three activities within one organizational unit, namely research funding and

Table 1 Dimensions for understanding the characteristics of university technology transfer organizations

\begin{tabular}{|c|c|}
\hline Dimensions & Descriptions \\
\hline 1. Centrality/autonomy & $\begin{array}{l}\text { Autonomy: the degree of power that a university technology transfer } \\
\text { organization has to make decisions regarding univesity-industry technology } \\
\text { transfer. UITT. Centrality: the level in decision-making: if it has to present their } \\
\text { decisions for approval to higher levels, it is centralized, and vice versa. }\end{array}$ \\
\hline 2. Specialization & $\begin{array}{l}\text { The level of specialization refers to the performance of the tasks/activities: (1) } \\
\text { valorization and IP services, (2) entrepreneurial support, (3) contract research } \\
\text { with industry and research funding, (4) consulting. }\end{array}$ \\
\hline 3. Standardization & $\begin{array}{l}\text { The activities for whether a unit following a formal specific/fixed technology } \\
\text { transfer procedure or not. }\end{array}$ \\
\hline 4. Exclusivity & $\begin{array}{l}\text { The dimension of exclusivity is used to determine if a university technology } \\
\text { transfer organization's services are for its host university only or its services are } \\
\text { available to other organizations. }\end{array}$ \\
\hline 5. Professionalization & $\begin{array}{l}\text { Professionalization represents the staff's certification obtainment as defined by } \\
\text { the professional associations of the university industry technology transfer } \\
\text { experts or their equivolent qualifications. }\end{array}$ \\
\hline 6. Funding & $\begin{array}{l}\text { It indicates the sources of funding supporting the operation of university } \\
\text { technology transfer organizations }\end{array}$ \\
\hline
\end{tabular}


Table 2 Typology of university technology transfer organizations

\begin{tabular}{|c|c|c|c|c|}
\hline Characteristic models & $\begin{array}{l}\text { Degree of } \\
\text { discipline } \\
\text { specialization }\end{array}$ & Degree of task specialization & Level of autonomy & $\begin{array}{l}\text { Degree of } \\
\text { exclusivity }\end{array}$ \\
\hline A: Classical TTO & $\begin{array}{l}\text { Discipline } \\
\text { integrated }\end{array}$ & $\begin{array}{l}\text { Fully integrated, backward } \\
\text { integrated, or forward } \\
\text { integrated }\end{array}$ & $\begin{array}{l}\text { Dependent (on } \\
\text { the university) }\end{array}$ & $\begin{array}{l}\text { Exclusive (to } \\
\text { the university) }\end{array}$ \\
\hline B: Autonomous TTO & $\begin{array}{l}\text { Discipline } \\
\text { integrated }\end{array}$ & $\begin{array}{l}\text { Fully integrated, backward } \\
\text { integrated, or forward } \\
\text { integrated }\end{array}$ & Independent & Exclusive \\
\hline $\begin{array}{l}\text { C: Discipline-integrated } \\
\text { Technology Transfer } \\
\text { Alliance }\end{array}$ & $\begin{array}{l}\text { Discipline } \\
\text { integrated }\end{array}$ & $\begin{array}{l}\text { Fully integrated, forward } \\
\text { integrated, or IP integrated }\end{array}$ & Independent & Non-exclusive \\
\hline $\begin{array}{l}\text { D: Discipline-specialized } \\
\text { Technology Transfer } \\
\text { Alliance }\end{array}$ & $\begin{array}{l}\text { Discipline } \\
\text { specialized }\end{array}$ & $\begin{array}{l}\text { Fully integrated, forward } \\
\text { integrated }\end{array}$ & Independent & Non-exclusive \\
\hline
\end{tabular}

Source: Modified from Schoen et al. (2014)

services, IP activities and management, and spin-off services. (2) A backward integrated technology transfer organizations when its activities are related to research funding and IP management and (3) a forward integrated technology transfer organization would be responsible for IP management and spin-put services.

\section{A review of studies on university technology transfer in China}

The literature on the university-industry technology transfer in China mainly deals with the institutional environment of university technology transfer, particularly the policy context (Huang et al. 2013; Wu and Zhou 2012) and legal framework (Orcutt and Shen 2010) and the productivity and performance of university technology transfer (Hong 2008; Miesing et al. 2014). Some studies indirectly address university technology transfer or university-industry links under the heading of innovation system (Xue 2006; Wang and Zhou 2008), Triple Helix (Cai 2014; Liu and Cai 2018; Cai and Liu 2015), and third mission (Wang et al. 2013). Meanwhile, some scholars have explored various forms of university-industry technology transfer (Dai and Xue 2011) and university technology transfer organizations, such as science parks (Zou and Zhao 2013), national technology transfer centers (Miesing et al. 2014), and university-run enterprises (Wang and Zhou 2009; Eun et al. 2006). These studies tend to explore specific forms of university-industry technology transfer and specific university technology transfer organizations, but a few studies provide overall pictures of university-industry technology transfer in China, and fewer explore various organizations' structural features.

To better understand the pattern and nature of university-industry technology transfer in China, Tang (2008) explored how universities transfer technology to industries through the institutional innovations since the 1980s. Liu and Jiang (2001) for the first time provided a systematic review of university-industry technology transfer in China; they identified five measures of university-industry technology transfer at Tsinghua University since 1995: the establishment of the University-Industry Cooperation Committee, technology transfer through collaboration with local governments, the establishment of high-technology companies in partnership with enterprises, forming networks of science and technology cooperation with universities, and the other collaborations with enterprises. Again examining Tsinghua University, Dai and Xue (2011) classified 
the activities of technology transfer into five models: technology contracts, intellectual property transfer and licensing, joint research centers, university science parks, and university-owned enterprises. Cai et al. (2015) explained why some university technology transfer organizations prevailed while others declined adopting a tentative organizational framework also in the case of Tsinghua University.

While acknowledging that all these studies form a foundation for further understanding university-industry technology transfer and university technology transfer organizations in China, some limitations can be observed as follows. First, the definitions of university technology transfer organizations in these studies are vague. Second, while many forms of university and industry links and university technology transfer organizations are discussed, few examine them from the perspective of their historical development. Third, none of them have systematically examined the organizational characteristics of university technology transfer organizations. These challenges call for proper analytical frameworks for studying university technology transfer organizations in China and among which the development of a typology of university technology transfer organizations in China is the most urgent.

To fill the research gap, we aimed to provide a comprehensive framework for understanding various types of university technology transfer organizations in China taking Tsinghua University as a specific case. We also consult the international literature and adapt it into the Chinese context.

\section{Analytical framework}

We consider the conceptual framework developed by Poglajen (2012) and Schoen et al. (2014) useful to understand the features of various university technology transfer organizations in China. However, since their studies were based on the European experience, we try to propose an enhanced framework by synthesizing their insights and apply it to the context of China. We use the dimensions mentioned in both Poglajen (2012) and Schoen et al. (2014) to describe the organizational characteristics of each model of university technology transfer organizations. The four dimensions of the degree of task specialization, level of autonomy, and degree of exclusivity come from Schoen et al. (2014), while the professionalization and the degree of disciplinary specialization from Poglajen (2012) that were overlooked in Schoen et al. (2014). Instead of treating funding as a separate dimension, we combine it with the dimension of autonomy following the resource dependency theory (Pfeffer and Salancik 1978). By integrating both frameworks, we propose the six dimensions in Table 3.

\section{Research method}

We will use a case study to test the usefulness of the six-dimension framework (Table 3) and then further develop a typology of university technology transfer organizations in China. Specifically, we choose Tsinghua University as our case, because as a leading science and technology university in China, Tsinghua University has been a pioneer in the commercialization of scientific achievements. Indeed, most types of university technology transfer organizations in the country were first piloted in Tsinghua University. The analysis is based on qualitative interviews and archival documents. The interviews were for gathering the real story about the history of the creation and the development of university technology transfer organizations around the following issues: 
Table 3 Integrated dimensions for understanding organizational characteristics of university technology transfer organizations

\begin{tabular}{|c|c|c|}
\hline \multirow[t]{2}{*}{ Dimensions } & \multicolumn{2}{|l|}{ Descriptions } \\
\hline & Variations & Explanations \\
\hline \multirow{2}{*}{$\begin{array}{l}\text { 1. Degree of discipline } \\
\text { specialization }\end{array}$} & Discipline integrated & Many disciplinary fields. \\
\hline & Discipline specialized & Certain disciplinary areas. \\
\hline \multirow[t]{3}{*}{$\begin{array}{l}\text { 2. Degree of task } \\
\text { specialization }\end{array}$} & Fully integrated & $\begin{array}{l}\text { It refers to university-industry technology transfer } \\
\text { at various stages and aspects: new product } \\
\text { development, technology consultation, IP } \\
\text { management on the university level, and services } \\
\text { supporting entrepreneurial activities. }\end{array}$ \\
\hline & Backward integrated & $\begin{array}{l}\text { It engaged in original product development } \\
\text { with funding and IP management but barely } \\
\text { supporting real entrepreneurship activities. }\end{array}$ \\
\hline & Forward integrated & $\begin{array}{l}\text { It focuses on supporting creating new firms } \\
\text { and the other entrepreneurship practices, } \\
\text { together with IP management. }\end{array}$ \\
\hline \multirow[t]{3}{*}{$\begin{array}{l}\text { 3. Level of autonomy } \\
\text { and centralities }\end{array}$} & Dependent & $\begin{array}{l}\text { Have limited autonomy in decision-making } \\
\text { in rules and budget allocation; obtain funding } \\
\text { and staffed from the host university. }\end{array}$ \\
\hline & Semi-independent & $\begin{array}{l}\text { Legally independent, while its board members } \\
\text { assigned by the university as crucial representatives. } \\
\text { Obtain donations from the host university, while its } \\
\text { further development dependent on its profitability. } \\
\text { The university bears a limited economic liability for } \\
\text { its operation. }\end{array}$ \\
\hline & Independent & $\begin{array}{l}\text { Legally independent with extensive rights in } \\
\text { decision-making in all respects with reporting to } \\
\text { upper level. The university only sponsors for its } \\
\text { creation, but not supporting or risking for its } \\
\text { further operation. }\end{array}$ \\
\hline \multirow[t]{2}{*}{ 4. Degree of exclusivity } & Exclusive & Service for the affiliated university only. \\
\hline & Non-exclusive & Service for many universities. \\
\hline \multirow[t]{3}{*}{ 5. Professionalization } & High level & $\begin{array}{l}\text { The staffs have a university degree or higher in } \\
\text { engineering or science; work experience in project } \\
\text { management, IP management, or business management; } \\
\text { or vocational certification in economics, judicial, patent } \\
\text { agent, and consultant agent. }\end{array}$ \\
\hline & Low level & $\begin{array}{l}\text { It is mainly staffed with researchers from the university } \\
\text { as their part-time job. The rest ones are barely met the } \\
\text { above requirements. }\end{array}$ \\
\hline & Non-professionalization & No specific professional qualifications required for staffs \\
\hline \multirow[t]{2}{*}{ 6. Standardization } & High standardized & $\begin{array}{l}\text { Formulated regulations and procedures for university- } \\
\text { industry technology transfer. }\end{array}$ \\
\hline & Low standardized & $\begin{array}{l}\text { No well-established regulations; the university-industry } \\
\text { technology transfer occurs on case by case. }\end{array}$ \\
\hline
\end{tabular}

Sources: Synthesized from Poglajen (2012) and Schoen et al. (2014)

- The reasons, background, and specific process for the university to organize different university technology transfer organizations to deal with the technology transfer.

- The functions, obligations, and staff compositions of these organizations.

- The organizational legitimacy and institutionalization process of various university technology transfer organizations, including their status in the university

- Formal regulations or informal rules on how to operate university technology transfer organizations.

- Possible challenges faced by the university technology transfer organizations. 
Table $\mathbf{4}$ Information of the interviewee

\begin{tabular}{|c|c|c|c|c|c|}
\hline No. & Code & Gender & $\begin{array}{l}\text { Interview date } \\
(\mathrm{DD} / \mathrm{MM} / \mathrm{YY})\end{array}$ & Affiliations of the interviewees & Duties of the interviewees \\
\hline 1 & $A_{1}$ & Female & $30 / 10 / 2011$ & $\begin{array}{l}\text { Scientific Research Institute } \\
\text { (清华大学科研院)* }\end{array}$ & Patent management and licensing \\
\hline 2 & $A_{2}$ & Female & $27 / 09 / 2012$ & Scientific Research Institution & Patent management and licensing \\
\hline 3 & $\mathrm{~B}_{1}$ & Male & 23/07/2012 & Scientific Research Institution & Patent management and licensing \\
\hline 4 & $\mathrm{~B}_{2}$ & Male & 03/10/2012 & Scientific Research Institution & Patent management and licensing \\
\hline 5 & $\mathrm{~B}_{3}$ & Male & 18/08/2018 & $\begin{array}{l}\text { Office of Technology Licensing } \\
\text { (成果与知识产权办公室) }\end{array}$ & $\begin{array}{l}\text { Scientific achievement registration, } \\
\text { technology assessment, developing } \\
\text { technology transfer plan }\end{array}$ \\
\hline 6 & C & Male & $27 / 11 / 2012$ & $\begin{array}{l}\text { Retired from the Science and } \\
\text { Technology Development } \\
\text { Department (科技开发处) in } \\
\text { the end of 1990s }\end{array}$ & $\begin{array}{l}\text { Facilitating cooperation between } \\
\text { the University and domestic } \\
\text { enterprises }\end{array}$ \\
\hline 7 & $\mathrm{D}_{1}$ & Male & 29/11/2012 & Scientific Research Institution & Scientific awarding \\
\hline 8 & $\mathrm{D}_{2}$ & Male & $17 / 08 / 2018$ & Scientific Research Institution & $\begin{array}{l}\text { Scientific awarding and technology } \\
\text { transfer }\end{array}$ \\
\hline 9 & E & Male & 29/09/2012 & Scientific Research Institution & $\begin{array}{l}\text { Intellectual property-related lawsuit, } \\
\text { technology transfer activities }\end{array}$ \\
\hline 10 & $\mathrm{~F}$ & Female & $30 / 11 / 2012$ & Scientific Research Institution & Scientific achievements management \\
\hline 11 & G & Male & $29 / 05 / 2012$ & $\begin{array}{l}\text { Retired from the Science and } \\
\text { Technology Development } \\
\text { Department in the end of } \\
\text { 1990s }\end{array}$ & $\begin{array}{l}\text { Facilitating cooperation between the } \\
\text { University and domestic enterprises }\end{array}$ \\
\hline 12 & $\mathrm{H}$ & Female & $21 / 05 / 2012$ & $\begin{array}{l}\text { School of life Science the } \\
\text { CapitalBio Corporation(博奥生 } \\
\text { 物集团有限公司), Tsinghua } \\
\text { Tsinghua Holdings Co., Ltd. } \\
\text { (清华大学控股集团) }\end{array}$ & $\begin{array}{l}\text { Multiple roles in different } \\
\text { organizations }\end{array}$ \\
\hline 13 & I & Male & $11 / 28 / 2012$ & $\begin{array}{l}\text { Faculty of Engineering Physics } \\
\text { and the Nuctech Company } \\
\text { Limited(同方威视技术股 } \\
\text { 份有限公司) }\end{array}$ & Dual roles in different organizations \\
\hline 14 & $J_{1}$ & Male & $25 / 02 / 2013$ & $\begin{array}{l}\text { Retired from the Science } \\
\text { and Technology Development } \\
\text { Department in the end of } \\
\text { 1990s }\end{array}$ & $\begin{array}{l}\text { A former leader of Science and } \\
\text { Technology Development Office in } \\
\text { 1990s }\end{array}$ \\
\hline 15 & $\mathrm{~J}_{2}$ & Male & 28/02/2013 & $\begin{array}{l}\text { Retired from the Science and } \\
\text { Technology Development } \\
\text { Department in the 1990s }\end{array}$ & $\begin{array}{l}\text { A former leader of Science and } \\
\text { Technology Development Office in } \\
\text { 1990s }\end{array}$ \\
\hline 16 & $J_{3}$ & Male & 04/06/2013 & $\begin{array}{l}\text { Retired from the Science and } \\
\text { Technology Development } \\
\text { Department in the 1990s }\end{array}$ & $\begin{array}{l}\text { A former leader of Science and } \\
\text { Technology Development Office in } \\
\text { 1990s }\end{array}$ \\
\hline 17 & K & Male & $24 / 02 / 2013$ & $\begin{array}{l}\text { The Institute of Science, } \\
\text { Technology and Society(清华 } \\
\text { 大学科学技术与社会研 } \\
\text { 究中心) }\end{array}$ & $\begin{array}{l}\text { Experts in science policy and } \\
\text { university-industry cooperation } \\
\text { research }\end{array}$ \\
\hline 18 & L & Male & $17 / 01 / 2013$ & $\begin{array}{l}\text { The Coway International } \\
\text { Technology Transfer Company } \\
\text { (科威国际技术转移有限责 } \\
\text { 任公司) }\end{array}$ & $\begin{array}{l}\text { Investment analysis on } \\
\text { commercialization of relevant } \\
\text { technologies }\end{array}$ \\
\hline 19 & M & Male & 02/04/2013 & $\begin{array}{l}\text { Tus-Holdings Co., Ltd. } \\
\text { (启迪控股股份有限公司) }\end{array}$ & Management \\
\hline 20 & $\mathrm{~N}$ & Male & $19 / 03 / 2013$ & $\begin{array}{l}\text { TusPark Management Co., Ltd. } \\
\text { (启迪科技园运营管理有 }\end{array}$ & $\begin{array}{l}\text { Providing services for developing } \\
\text { start-ups in the Park }\end{array}$ \\
\hline
\end{tabular}


Table 4 Information of the interviewee (Continued)

\begin{tabular}{|c|c|c|c|c|c|}
\hline No. & Code & Gender & $\begin{array}{l}\text { Interview date } \\
(\mathrm{DD} / \mathrm{MM} / \mathrm{YY})\end{array}$ & Affiliations of the interviewees & Duties of the interviewees \\
\hline & & & & 限公司) & \\
\hline 21 & $\mathrm{O}$ & Male & $25 / 01 / 2013$ & $\begin{array}{l}\text { China Institute for Science and } \\
\text { Technology Policy at Tsinghua } \\
\text { University }\end{array}$ & $\begin{array}{l}\text { Research on science } \\
\text { policy and technology transfer policy }\end{array}$ \\
\hline 22 & $P$ & Male & $02 / 07 / 2013$ & $\begin{array}{l}\text { Both Science and Technology } \\
\text { Development Department and } \\
\text { the TAC company in 2013(华清 } \\
\text { 农业开发有限公司) }\end{array}$ & Dual roles \\
\hline 23 & Q & Male & 23/07/2013 & Scientific Research Institution & Technology transfer activities \\
\hline
\end{tabular}

*Scientific Research Institution is our translation of 清华大学科研院, although its official translation on the website of Tsinghua University is the Office of Scientific R\&D. Since there will be several subordinate offices within the Institute, these offices may confuse with the Office of Scientific R\&D

Most interviews were conducted during 2011-2015, and two supplementary interviews were conducted in 2018. The interviewees were practitioners involved in technology transfer at Tsinghua University (see Table 4). Some of them were interviewed more than once, in order to make the differences, for example by using $A_{1}$ and $A_{2}$ to represent the two interviews of the same person conducted in different times.

The interviews were transcribed and analyzed following the framework (Table 3). When tracing the history of university technology transfer organizations in Tsinghua University over the past 30 years, the sources of information rely mainly on those people currently working in the field. We also tried to search archives and historical documents that were gathered from the Yearbook of Science and Technology of Tsinghua University (1990 2012), Yearbook of Tsinghua Holding Company (2004 2010), and the other annual reports, law decrees, press releases, and publications.

\section{Type of university technology transfer organizations in Tsinghua University from the 1980s to the 2010 s}

In this section, we will use the integrated framework with six dimensions (Table 3) to distinguish and analyze different university technology transfer organizations at Tsinghua University, reflecting the development of university technology transfer organizations in China (Cai et al. 2015), to verify the usefulness of the frameworks in the Chinese context.

To respond to the policy imperatives encouraging universities' regional engagement, various types of university technology transfer organizations have been developed since the 1980s in China. In addition, the government has tried to facilitate technology transfer through some national science and technology programs, such as the National Program on Key Basic Research Project of China (973 Program), the National High-Tech R\&D Program of China (863 Program), the National Key Technology Research and Development Program, and the "Spark" Program. Although these programs are not analyzed in this study given our specific focus on university technology transfer organizations, they are indeed intertwined with university technology transfer organizations. To better perform their functions, university technology transfer organizations are expected to utilize and integrate all the opportunities provided by the programs. 
Dawn of the development of university technology transfer organizations (pre-1980s)

During the period of centrally planned economy between the 1950s and the early 1980s, universities' scientific projects were commissioned by the State to solve technological problems in the industry. Under such a system, many universities established a new type of department in their administrative systems responsible for research projects management, often called the Scientific Research Department (科学研究处). Such organizations did not engage technology transfer activities. Rather, their primary tasks were to organize research, improve scientific qualities, promote interdisciplinary cooperation, and make the best use of research funding.

In Tsinghua University, the Scientific Research Department (科学研究处) was founded in 1956 with three sub-divisions responsible respectively for the management of postgraduate students, research planning, and laboratories. Later, it came to include a new mission for purchasing and managing the property (laboratory equipment or apparatus) of the university. It expanded again in 1959 by establishing two new divisions-the Production Office (生产办公室) and Information and Material Office (生产 科和情报资料科), which assumed responsibility for managing a factory affiliated to the university. It was small in scale and served both as an important platform for training students' practical capabilities and piloting manufacturing prototypes of the scientific results developed by academics before releasing them into the marketplace for mass production.

Until the early 1980s, the basic function of the Scientific Research Department was to administrate the scientific projects of the university commissioned by the State, rather than serving as an intermediary organization to transfer knowledge from university to industry. Therefore, such an organization cannot be considered a genuine university technology transfer organization as we understand this today.

\section{Development of university technology transfer organizations in the 1980s and early 1990s}

With the reform and opening policy and the establishment of a market-oriented economic system in the 1980s, university technology transfer organizations in a true sense appeared, but mainly of two types, namely (1) original technology transfer offices under the university administration and (2) university-run enterprises. The former were established specifically for coping with the emerging needs for university-industry technology transfer. Although the latter were originally developed to generate revenue for universities (Xue 2003), they soon became a unique approach of commercializing university technology. In Tsinghua University, the typical examples of the two types of university technology transfer organizations are respectively the Science and Technology Development Service Department (科学技术开发服务部) established in 1983 and the Science and Technology Development Corporation (科技开发总公司) established 5 years later in 1988. Both had experienced a series of organizational changes to better adapt to the environment.

In 1983, the Scientific Research Department had a second organization name-the Science and Technology Development Service Department. The latter became the sole unit taking overall responsibilities to manage the University's technology transfer activities. In practice, the Department was mainly for matching the technologies developed 
by the academic staff and academic departments with enterprises, but not for managing the processes of commercialization of the technologies. The staff we interviewed who used to deal with the intellectual property lawsuits in the university noted that:

In the 11th Science and Technology conference held at Tsinghua University in April 1984, the President of the University proposed several concrete measures to solve the problem of the decentralized scientific research management and scientific resources scattered in different departments. It was believed that the establishment of the Science and Technology Development Service Department would provide unified services facilitating technology transfer. (Interviewee: E).

The interviewee J noted that the launch of the Science and Technology Development Service Department is one of the significant decisions by the University in the 1980s. The other milestone was the formulation of "Millions of Yuan Benefit Bonus" policy to promote technology transfer activities. He also reminded that there were also opposing views arguing that the technology transfer function (recognized as business behavior) should not be included in the university, and thus, it was unreasonable to have the Science and Technology Development Service Department inside the university. As a consequence, the Science and Technology Development Service Department was therefore separated from the Scientific Research Department during the period of 1983-1990, aiming for devloping it as a independent entity. However, there are two competing oppinions regarding the establishment of the Department, as noted by the interview J as follows. Becasues of the dillemas, the Department was re-organised to be more integrated in the University's administration (to be discussed in the next sub-section).

There were two considerations for establishing the Department. First, it could help sign the technology transfer contract agreements on its own name (to avoid the University being directly involved in business activiteis). Second, it independently dealt with legal disputes and leaving the University free from legal complications. Meanwhile, the functions of the Department were challenged by people from both inside and outside of the University. Although it was an independent department, it was not the real owner of scientific achievements of Tsinghua University, neither a real legal entity. Thus, when the real legal disputes arise, it cannot afford the legal responsibilities. (Interviewee: $J_{1}$ )

Due to the weak capacity of Chinese industries to absorb technologies from the university and the willingness of the university to increase the efficient exploitation of research outputs, the University decided to create a university-run enterprise, to develop the university-based technology on its own. Against this background, the Science and Technology Development Corporation was set up in 1988. The initial members of this company were mainly employees transferred respectively from the Science and Technology Development Service Department and the Scientific Research Department. In August 1995, the Tsinghua University Enterprises Group (清华大学企业集团) was founded approved by the Ministry of Education and the State Economic and Trade Commission, to be responsible for the management of all the enterprises by Tsinghua University, no matter it was created by the faculties or the departments. "The 
university-run enterprises or factories were the most important platform for technology transfer since the middle 1980s, and there was a saying 'you will found a company once you open a door of a laboratory," noted by the interview of $A_{1}$.

Interview $\mathrm{J}_{2}$ explained the background of developing university-run enterprises in Tsinghua University:

After many failed negotiations with the enterprises to invest in the scientific research and consideration concerning relatively weak absorption capacity of innovation for the enterprise, the University found it would be easier and better to have its own enterprises to commercialize the technology developed by the University. While there were no specific department responsible for the scientific result's operation and the business, the Science and Technology Development Corporation has transformed into Tsinghua Unigroup (清华紫光集团) in 1993 with Zhang Benzheng (张本正) as the CEO. However, once Tsinghua Unigroup became a specialized enterprise, it has focused exclusively on information industry. The university was still needing other forms of organizations to take responsibilities of commercialization of knowledge for all disciplines. Then the Coway International Technology Transfer Company (科威国 际技术转移有限公司) was set up in 2002, and its initial staff members were from the Science and Technology Department. They would exploit the potential commercializing value of the technologies of the University and look for and negotiate with enterprises that need the technologies (Intervifewee: $J_{2}$ )

The organizational characteristics of the two types of university technology transfer organizations are summarized in Table 5.

\section{Development of university technology transfer organizations since the beginning of the 1990s}

The 1990s saw the emergence of three new types of university technology transfer organizations: renewed technology transfer offices, National Engineering Research Centers, and university science parks. All types of university technology transfer organizations were first tested in Tsinghua University along with the reform of the scientific management system carried out by the university in 1990 .

In 1990, the Science and Technology Development Service Department (科学技术 开发服务部) and Scientific Research Department (科学研究处) were merged again and renamed into the Science and Technology Department in 1992 (科学技术处) as a renewed technology transfer organization of Tsinghua University. The Office at this point integrated the task of research projects and the outputs management, IP management and licensing, and technology transfer services into a single organization. Compared with the previous technology transfer office-the Science and Technology Development Service Department-the task of the renewed organization is more comprehensive, but it lost its former legally independent status when it became affiliated as an internal organization of the administrative system of Tsinghua University. In 2003, the other four new offices were created within the Science and Technology Department, namely the Intellectual Property Office (知识产权办公室), the Research Institutions Management Office (科研机构 管理办公室), the Oversees Contract Office (海外项目部), and the Military Project 
Table 5 Organizational characteristics of university technology transfer organizations at Tsinghua University during the 1980s-1990s

\begin{tabular}{|c|c|c|}
\hline \multirow[t]{2}{*}{ Dimensions } & \multicolumn{2}{|l|}{ Description } \\
\hline & $\begin{array}{l}\text { Science and Technology Development } \\
\text { Service Department(1983-1990) }\end{array}$ & $\begin{array}{l}\text { Science and Technology } \\
\text { Development Corporation }\end{array}$ \\
\hline $\begin{array}{l}\text { 1. Degree of discipline } \\
\text { specialization }\end{array}$ & $\begin{array}{l}\text { Discipline integrated: It provides } \\
\text { services of university-industry } \\
\text { technology transfer in many } \\
\text { disciplines }\end{array}$ & $\begin{array}{l}\text { Discipline specialized: It focuses } \\
\text { on three domains: mechanical, } \\
\text { electrical, and computer science. }\end{array}$ \\
\hline $\begin{array}{l}\text { 2. Degree of task } \\
\text { specialization }\end{array}$ & $\begin{array}{l}\text { Backward integrated: Tasks include } \\
\text { project management, technology } \\
\text { consultation, making science and } \\
\text { technology strategies for the university, } \\
\text { and science and technology information } \\
\text { publication. }\end{array}$ & $\begin{array}{l}\text { Forward integrated: It aims at } \\
\text { technological product development, } \\
\text { production, and sales in the three } \\
\text { fields mentioned above. }\end{array}$ \\
\hline 3. Level of autonomy & $\begin{array}{l}\text { Independent: aiming to be legally } \\
\text { independent, to address lawsuits, } \\
\text { thus trying to relieve the university } \\
\text { from possible legal disputes. Its } \\
\text { expenditure and personnel were } \\
\text { from Tsinghua University. }\end{array}$ & $\begin{array}{l}\text { Dependent: It was founded as an } \\
\text { enterprise but without independent } \\
\text { legal status and fully controlled by } \\
\text { Tsinghua University. }\end{array}$ \\
\hline 4. Degree of exclusivity & $\begin{array}{l}\text { Exclusive: Serves for Tsinghua University } \\
\text { exclusively. }\end{array}$ & $\begin{array}{l}\text { Exclusive: Commercialization of } \\
\text { technology only in certain areas of } \\
\text { Tsinghua University. }\end{array}$ \\
\hline 5. Professionalization & $\begin{array}{l}\text { Low level: Staffed with researchers } \\
\text { with engineering background or with } \\
\text { scientific project management experience, } \\
\text { with less experience in commercializing } \\
\text { technology to the market. }\end{array}$ & $\begin{array}{l}\text { Low level: The initial staff members } \\
\text { were mainly from the Science and } \\
\text { Technology Development Services and } \\
\text { researchers from different faculties of } \\
\text { Tsinghua University. Most staff } \\
\text { members had a university degree in } \\
\text { engineering or science, with little work } \\
\text { experience in scientific project or firm } \\
\text { management }\end{array}$ \\
\hline 6. Standardization & $\begin{array}{l}\text { High level: The university issued six } \\
\text { regulations concerning the management } \\
\text { of technology transfer contracts, the } \\
\text { application procedure, and the approval } \\
\text { reviewer forms during 1985-1995 to } \\
\text { standardize the management of " } \\
\text { horizontal" scientific projects (with funding } \\
\text { from the enterprises). }\end{array}$ & $\begin{array}{l}\text { Low level: No regulations were made } \\
\text { on university-run enterprises until "the } \\
\text { Regulations of University-run Enterprises } \\
\text { in Tsinghua University" were issued in } \\
\text { 1993, followed by other relevant } \\
\text { regulations formulated up to 1998. Thus, } \\
\text { the earlier university-run enterprises } \\
\text { remained at a low level of standardization } \\
\text { in 1980s. }\end{array}$ \\
\hline
\end{tabular}

Office (军工部). Given the expanded functions and enlarged organizational size, the Science and Technology Development Department was renamed as the Scientific Research Institute (科研院) at the same time. Among these offices, the Intellectual Property Office specialized on technology transfer activities of Tsinghua University. Due to rapid expansion of technology transfer activities, the Intellectual Property Office became independent from the Scientific Research Institute and renamed as the Office of Technology Licensing (成果与知识产权管理办公室) in 2015. The development of various technology transfer offices as part of university administration is shown in Fig. 1.

Inspired by the US government's creation of engineering research centers in the 1980s for more efficient use of fundamental engineering knowledge to solve problems in the industry, the Chinese government began to establish National Engineering Research Centers (NERCs) since 1992. The primary objectives are as follows: (1) to promote the application of science and technology (S\&T) contributing to economic development, (2) to promote the growth of emerging 


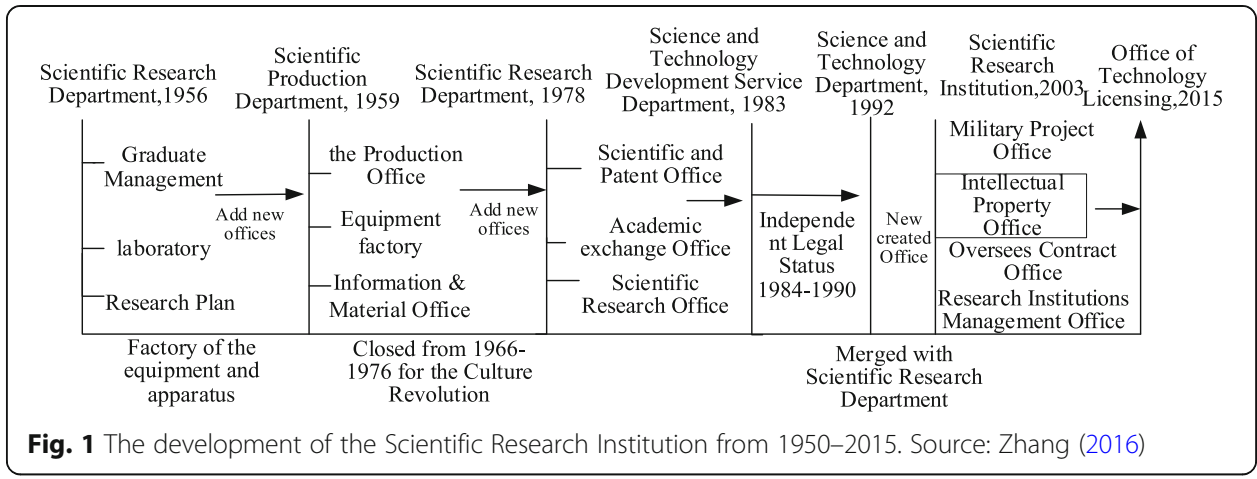

industries and upgrading traditional industries via the diffusion of engineering research findings, (3) to build up R\&D bases for technology innovation and industrialization by educating human resources for engineering and improving the laboratory environments, and (4) to enhance the industries' capacity and competency in specific domains. The NERCs' establishment was approved by the National Development and Reform Commission with various funding sources, including the State budget, bank loans, self-financing, and enterprise investment. Initially, the NERCs were not legally independent but affiliated to different research institutes, universities, or enterprises. The first NERC was the National Computer Integrated Manufacturing System (CIMS) (国家计算机集成制造系统工 程研究中心) founded in Tsinghua University in 1992.

Partly inspired by the legends of Stanford Science Park, Cambridge Science Park, and many others, the first Chinese university-based science park was founded by Northeastern University in 1988. As the pioneer in establishing university science parks, its construction followed a top-down approach, in which the government formulated overall strategic planning and provided initial funding as well as other supportive measures for the university science park. In 1994, the Tsinghua Science Park Development Center (TusPark) (清华大学科技园开发中心) was founded as an internal organization of the university and responsible for the construction of the university's science park with a government land allocation of $5,581,500 \mathrm{ft}^{2}$. Since there were voices that complained about actively commercial activities by those enterprises founded by the faculties or departments on campus, TusPark's establishment provided an ideal place to move these enterprises out of campus, to make the geographical separation between the university and the enterprises (Interview $\mathrm{J}_{2}$ ).

Five years later, Tsinghua University Science Park was approved as the national flagship university science park. In 2000, the science park, originally under the direct administration of the university, was transformed to the limited liability company (TusPark Construction Holdings Co., Ltd.). After 4 years of development, the company grew into a large group of enterprises, known as the Tus-Holdings Co., Ltd. TusPark is the key platform of incubating high-tech start-ups of Tsinghua University. The organizational characteristics of the three types of technology transfer organizations discussed in this section are presented in Table 6. 


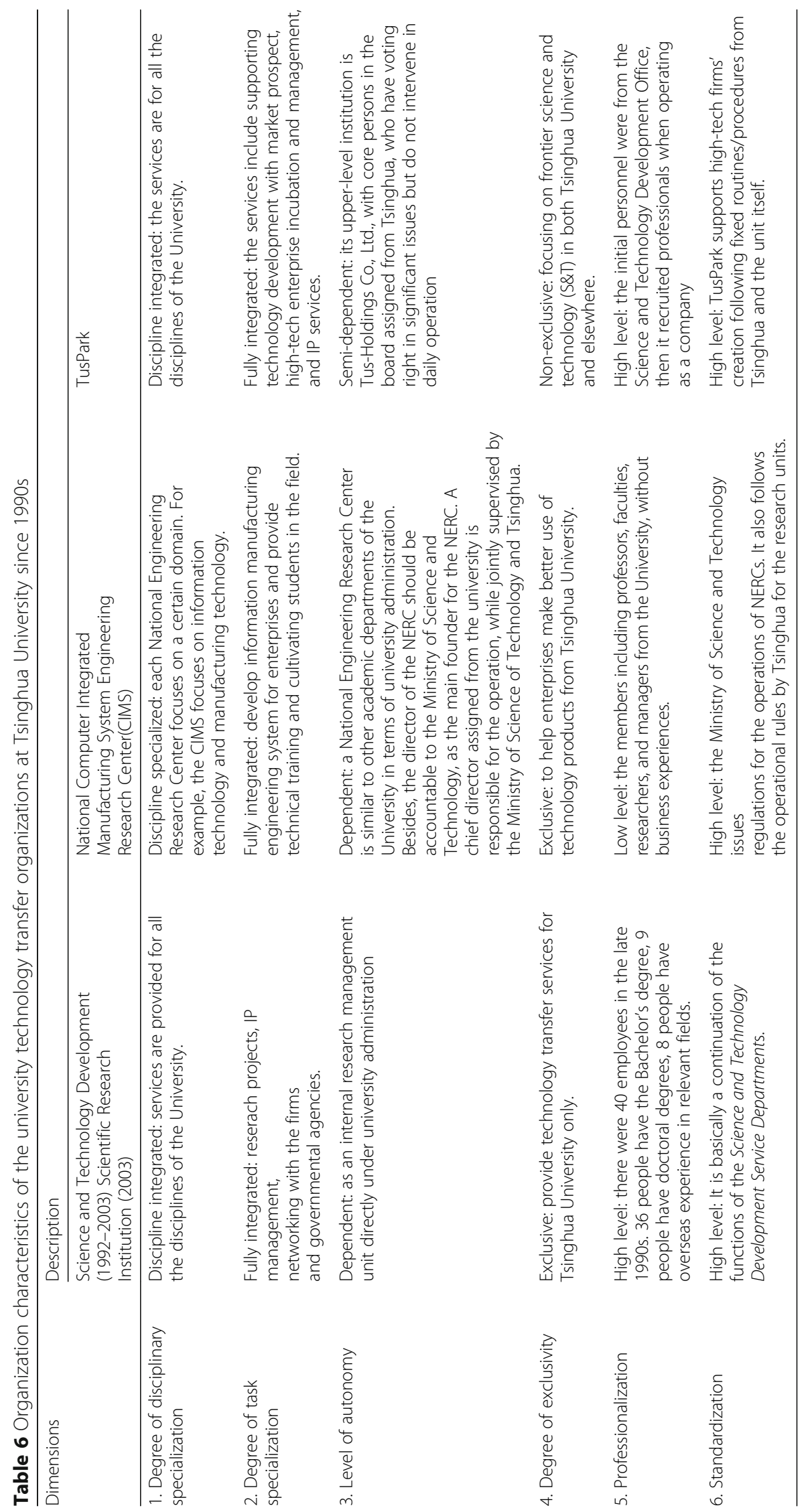


Technology transfer organization development since the late 1990s

Since the late 1990s, two types of new university technology transfer organizations have emerged: university-owned enterprises (transformed from university-run enterprises) and joint research centers with enterprises or regional governments.

In the late 1980s, there were in total 164 Tsinghua University-run enterprises created by individual faculties or at the departmental level. Soon after, numerous problems occurred. First, there were ambiguous relationship concerning property ownership between the university and the company. Second, opponents argued that it was unreasonable for the host university, as a public non-profit organization, to bear liability for the losses and disputes of those enterprises. Third, since university-run enterprises were usually located on campus, this enriched the commercial atmosphere, contrary to traditional academic norms. Finally, if these enterprises were run by the University, they would never become real business entities.

To address the problems, the Chinese Central Government issued a decision on the reform of university-run enterprises in 2001, taking Peking University and Tsinghua University as the testbeds for implementation. One of the countermeasures in the decision was to prohibit the university to directly set up enterprises in the future. As a response, the strategy of Tsinghua University was to manage all the university-run enterprises via a new holding corporation. Based on the Tsinghua Enterprises Group (清华大学企业集团) as the superior organization for university-run enterprises, the Tsinghua Holdings Co., Ltd. (清华控股集团) was founded in 2003; it is a limited company with the approval of the State Council of the People's Republic of China. As a completely state-owned limited liability corporation, the Tsinghua Holdings Co., Ltd. became sole or partial shareholder of all the previous university-run enterprises. It has a number of affiliated corporations, such as the abovementioned ones: Tsinghua Unisplendour (Group) (清华紫光集团), Tus-Holdings Co., Ltd. (启迪控股), and CapitalBio Corporation (博奥生物集团有限公司). Tsinghua Holdings Co., Ltd. holds shares in those companies on behalf of Tsinghua University. Tus-Holdings Co., Ltd provides incubation services, financial investment, entrepreneurship training, open platform, while TusPark is its key platform to realize such goal. It sets up the TusPark Management Co., Ltd. (启迪科技园运营管理有限公司) responsible for the development, construction, and operation of TusPark. With the rapid development of Tus-Holdings Co., Ltd., it invested more than 200 innovative business bases and has provided incubation services to over 5000 enterprises. In 2015, the TUS International was set up as TUs Holdings' platform to extend the international business, as well as to list on the stock market in Hong Kong.

An illustration of the Tsinghua Holdings Co, Ltd. and their sub-companies is described in Fig. 2. The organizational features of holding companies are presented in Table 7.

In the late 1990s, other types of organizations for technology transfer were initiated by the University in collaboration with regional governments and enterprises to serve broad demands for innovation and economic development in the country. The two types of university technology transfer organizations are (1) university-region joint research institutes and (2) university-enterprise joint research centers.

Based on Tsinghua University's extensive scientific cooperation with the provincial and municipal governments, Tsinghua University and some regional governments jointly established university-region joint research institutes. These are as follows: (1) 


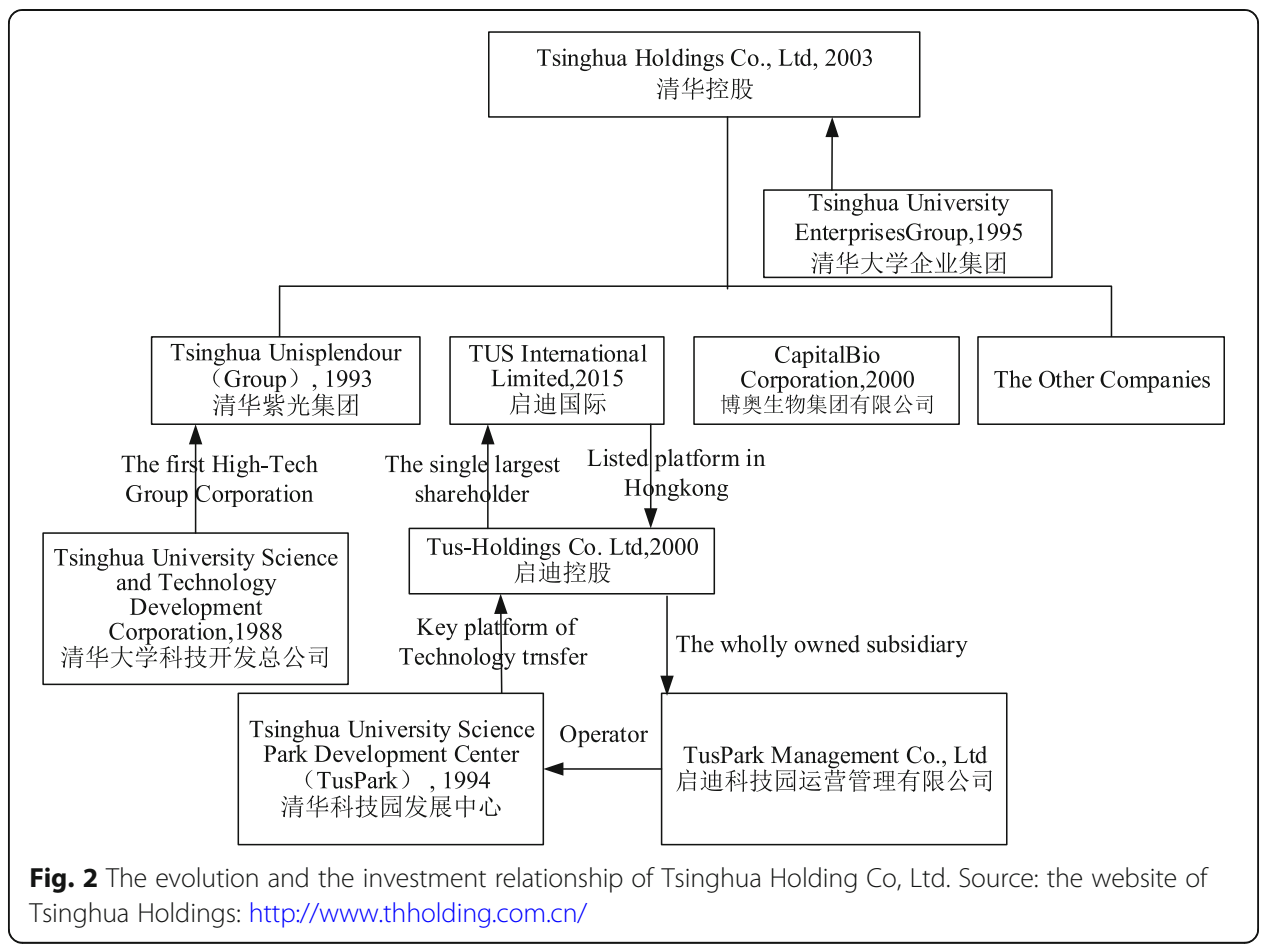

Table 7 Organizational characteristics of Tsinghua Holdings Co., Ltd.

\begin{tabular}{|c|c|}
\hline Dimensions & Description \\
\hline $\begin{array}{l}\text { 1. Degree of disciplinary } \\
\text { specialization }\end{array}$ & $\begin{array}{l}\text { Discipline integrated: it invests in enterprises which are engaged in the fields of } \\
\text { information technology, energy conservation and environment protection, } \\
\text { integrated circuit and biological health, technical service and knowledge industry, } \\
\text { and other multiple disciplines. }\end{array}$ \\
\hline $\begin{array}{l}\text { 2. Degree of task } \\
\text { specialization }\end{array}$ & $\begin{array}{l}\text { Fully integrated: the tasks range from legal management, } \\
\text { commercialization of scientific and technological achievements, high-tech firms' } \\
\text { incubation, investment management, and asset/capital operation. Its aim is to } \\
\text { maintain and increase the state-owned assets' value. }\end{array}$ \\
\hline 3. Level of autonomy & $\begin{array}{l}\text { Semi-dependent: it is a state-owned limited liability corporation, legally } \\
\text { independent, undertaking sole risk for its investment and losses. Generally, } \\
\text { the university does not intervene in the operation and development, but exerts } \\
\text { influence on crucial issues via an ad hoc organization -- the Office of Business } \\
\text { Asset Administration-established in } 2006 \text {. }\end{array}$ \\
\hline 4. Degree of exclusivity & $\begin{array}{l}\text { Exclusive: it is responsible for the invested enterprises by the Tsinghua Holding } \\
\text { Ltd. only }\end{array}$ \\
\hline 5. Professionalization & $\begin{array}{l}\text { High level: it sets up the Technology Assets Operation Center in } 2013 \text { and } \\
\text { recruited } 8 \text { full-time employees responsible for professional management of } \\
\text { the holding company. They maintain close and frequent contact with various } \\
\text { academic departments at Tsinghua University to identify promising technologies } \\
\text { with potential commercial prospects. The staff have work experience in business } \\
\text { management, legal affairs, patent application and licensing, etc. }\end{array}$ \\
\hline 6. Standardization & $\begin{array}{l}\text { High level: in 2013, the Holding Corporation issued the Regulations on the Equity } \\
\text { Stock and Technology Capitalist and the Regulations on Investment of Enterprises } \\
\text { in Tsinghua University. }\end{array}$ \\
\hline
\end{tabular}


the Research Institute of Tsinghua University in Shenzhen (深圳清华大学研究院) established in 1996; (2) the Research Institute of Tsinghua in Beijing (北京-清华工业开 发研究院) established in 1998, located in TusPark; (3) the Research Institute of Tsinghua in Hebei province (河北清华发展研究院) founded in 2002; and (4) the Yangtze Delta Region Institute of Tsinghua University in Zhejiang province (浙江清华长三角研 究院) established in 2003. All these joint institutes are public service organizations mainly for R\&D and technology transfer. The regional governments provide funding for the operation of these joint institutions, while the Tsinghua University contributes with human resources.

Meanwhile, a number of university-enterprise technology transfer centers were established based on the agreements between Tsinghua University and enterprises. The enterprises provide funding for these joint centers for strengthening R\&D for the enterprises. By 27 March 2018, there were 112 such kind of jointly centers. Some examples are Tsinghua-Toyota Jointly R\&D Center (清华大学丰田研究中心) and Tsinghua-BP Clean Energy Research and Education Center in 2003 (清华-BP清 洁能源研究与教育中心), Tsinghua-Toshiba Energy and Environment Center in 2005 (清华-东芝能源与环境研究中心), and the Tsinghua-Origin Water Company of the Environment Membrane Technology Center in 2008 (清华大学碧水源膜技术研 发中心).

There had been no regulations on creating, operating, and financing university-enterprise joint research centers until the launch of the Regulations on the Management of Research Institutions issued by Tsinghua University in 2006 (revised in 2015). According to the Regulations, to set up such jointly center with enterprises, the sponsoring party should submit an application to the university committee for approval. One important criterion is that the amount of entreprise investment to the joint centers must be no less than 12 million RMB in 3 years.

To understand both the university-regional joint research institutes and universityenterprise joint research centers, we respectively choose two examples for illustration in Table 8.

\section{Discussions}

\section{Eight university technology transfer organizations}

The above analysis demonstrates that eight types of university technology transfer organizations have been successively established at Tsinghua University, namely (1) original technology transfer office (OTTO), (2) renewed technology transfer office (RTTO), (3) university-run enterprises (UREs), (4) university science parks (USPs), (5) university-owned enterprises (UOEs), (6) national engineering research centers (NERCs), (7) university-region joint research institutes (URJRI), and (8) university-enterprise joint research centers (UEJRC):

1. Original technology transfer office (with its specific name Science and Technology Development Service Department during 1983-1992) is responsible for the overall technology transfer activities and technological consulting and services, to organize research groups to accomplish commissioned scientific research projects by the government or the enterprises. 
Table 8 Organizational characteristics of university-region joint research institutes and universityenterprise joint research centers

\begin{tabular}{|c|c|c|}
\hline \multirow[t]{2}{*}{ Dimensions } & \multicolumn{2}{|l|}{ Description } \\
\hline & $\begin{array}{l}\text { The Research Institute of Tsinghua } \\
\text { University in Beijing }\end{array}$ & $\begin{array}{l}\text { Tsinghua-BP Clean Energy Research and } \\
\text { Education Center }\end{array}$ \\
\hline $\begin{array}{l}\text { 1. Degree of disciplinary } \\
\text { specialization }\end{array}$ & $\begin{array}{l}\text { Discipline integrated: its services are } \\
\text { for all possible needs of university- } \\
\text { industry technology transfer in Beijing. }\end{array}$ & $\begin{array}{l}\text { Discipline specialized: it is specialized in } \\
\text { energy technology, energy system, and } \\
\text { strategy and policy analysis. }\end{array}$ \\
\hline $\begin{array}{l}\text { 2. Degree of task } \\
\text { specialization }\end{array}$ & $\begin{array}{l}\text { Fully integrated: the tasks include R\&D, } \\
\text { high-tech firms' incubation, innovation } \\
\text { capacity development for local firms, } \\
\text { and regional innovation context } \\
\text { improvement. }\end{array}$ & $\begin{array}{l}\text { Backward integrated: the tasks are to } \\
\text { conduct R\&D projects for the enterprises } \\
\text { and even the government, particularly for } \\
\text { improving the energy efficiency of coal } \\
\text { power plants and the sustainable energy } \\
\text { development in China. }\end{array}$ \\
\hline 3. Level of autonomy & $\begin{array}{l}\text { Semi-dependent: it is a public } \\
\text { institution but enjoys certain level of } \\
\text { autonomy. It is under the joint } \\
\text { administration of Tsinghua University } \\
\text { and Beijing Municipal government. }\end{array}$ & $\begin{array}{l}\text { Dependent: it invested one-time with } \\
0.4 \text { million dollars of its creation as an } \\
\text { independent research institution in } \\
\text { Tsinghua. There are agreements between } \\
\text { the two collaborations while obeying the } \\
\text { rules of university-industry technology } \\
\text { transfer in Tsinghua in general. }\end{array}$ \\
\hline 4. Degree of exclusivity & $\begin{array}{l}\text { Non-exclusive: it is now serving as a } \\
\text { platform to address technology transfer } \\
\text { problems for both public and private } \\
\text { organizations beyond the Tsinghua } \\
\text { University. }\end{array}$ & $\begin{array}{l}\text { Exclusive: it focuses on utilizing relevant } \\
\text { research outputs of Tsinghua University } \\
\text { to resolve technological challenges of } \\
\text { the cooperating enterprise. }\end{array}$ \\
\hline 5. Professionalization & $\begin{array}{l}\text { High level: it employs professional } \\
\text { staffs for its operation, including } \\
\text { technology transfer specialists and } \\
\text { intellectual property managers. }\end{array}$ & $\begin{array}{l}\text { Low level: the team members are } \\
\text { organized by professors and faculties, } \\
\text { who have less experience in university- } \\
\text { industry technology transfer }\end{array}$ \\
\hline 6. Standardization & $\begin{array}{l}\text { High level: } 5 \text { functional departments } \\
\text { in the Joint Research Institute are } \\
\text { responsible for project management, } \\
\text { innovation services, investment, and } \\
\text { education training, guided by clear } \\
\text { regulation of the Institute. }\end{array}$ & $\begin{array}{l}\text { High level: its operations are in } \\
\text { accordance with the general regulations } \\
\text { of Tsinghua for jointly research } \\
\text { institutions with enterprises. }\end{array}$ \\
\hline
\end{tabular}

2. Renewed technology transfer offices (Science and Technology Development Department established in 1992, Scientific Research Institute since 2003) are responsible for scientific product registration, scientific awarding, patent management, technology transfer, and related legal issues. These organizations also assist university researchers to make plans for technology transfer especially on the commercial dimension.

3. University-run enterprises were those founded in the 1980s and 1990s by the staff members and academic units of the University based on the advantage of their knowledge and technologies. The examples are the Science and Technology Development Corporation established in 1988 and the Tsinghua University Enterprises Group established in 1995.

4. University science parks (such as TusPark) focusing on science and technology services, incubation of start-ups, and operation of start-ups by providing technology, industry, and capital support.

5. University-owned enterprise (i.e., Tsinghua Holdings Co., Ltd. established in 2003) has been working on bringing Tsinghua University's scientific and technological achievements to the market though participating in the management as a shareholder.

6. National Engineering Research Centers (since 1990s) are supported by the State to promote effective use of core technologies to resolve the problems in the industry. 
7. University-region joint research institutes are joint public organizations between Tsinghua University and regional government for make use of the scientific achievements of the University to promote the regional innovation development.

8. University-enterprise joint research centers are the collaboration between the University and enterprises to solve the specific technology problem or meet technological demands of the collaborating enterprises

Based on the findings of the present study and an early study on the institutionalization of university technology transfer organizations in Tsinghua University (Cai et al. 2015), we position the evolution of these organizations in Fig. 3.

Although the path dependencies of all models of university technology transfer organizations provide a contextual background to better understand each model of university technology transfer organization, the focus of our study is to distinguish the models in terms of their six dimensions of organizational characteristics. To make our descriptions and explanations of the organizational characteristics of the university technology transfer organizations more concrete, we provide examples linked to each model of university technology transfer organizations (see Table 9). We selected these examples either because they are unique in certain types or they are typical among those similar kinds considered by the interviewees. In Table 9, we also compare the types of university technology transfer organizations in Tsinghua University with Schoen et al. (2014)'s typology of university technology transfer organizations in the European context. While the organizational characteristics of the eight university technology transfer organizations have been provided in detail in the previous section, a summary is shown in Table 10.

We also found some unique organizational features of university technology transfer organizations at Tsinghua University and likely in the Chinese context in general compared to the European experience observed by Poglajen (2012) and Schoen et al. (2014). First, type B (autonomous technology transfer organizations) in the category of Schoen et al. (2014) is less visible in China. This is because most of the university technology transfer organizations in Tsinghua University are dependent or semi-independent on the host university in spite of their "independent" legal status. For instance,

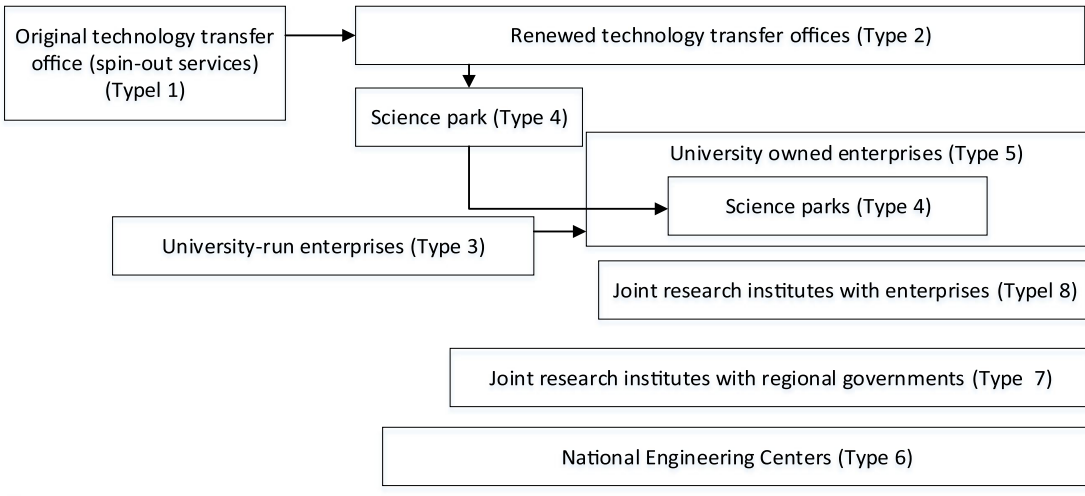

Fig. 3 Evolution of University Technology Transfer Organizations in Tsinghua University. Modified from (Cai et al. 2015) 
Table 9 The eight example models of university technology transfer organizations at Tsinghua University

\begin{tabular}{|c|c|c|c|}
\hline Models of UTTOs & Examples & $\begin{array}{l}\text { Period of } \\
\text { existence }\end{array}$ & $\begin{array}{l}\text { Compared to the typology } \\
\text { in Schoen et al. (2014) }\end{array}$ \\
\hline $\begin{array}{l}\text { Type } 1 \text { Original technology } \\
\text { transfer offices }\end{array}$ & $\begin{array}{l}\text { Science and Technology } \\
\text { Development Service } \\
\text { Department }\end{array}$ & $1983 \sim 1990$ & Corresponding to Type A \\
\hline $\begin{array}{l}\text { Type } 2 \text { Renewed technology } \\
\text { transfer offices }\end{array}$ & $\begin{array}{l}\text { Science and Technology } \\
\text { Department \& Scientific } \\
\text { Reserach Institute }\end{array}$ & $1992 \sim$ & Corresponding to Type A \\
\hline Type 3 University-run enterprises & $\begin{array}{l}\text { Tsinghua University Science } \\
\text { and Technology Development } \\
\text { Corporation }\end{array}$ & 1988 1992 & Not being reflected \\
\hline Type 4 University science parks & $\begin{array}{l}\text { Tsinghua University Science } \\
\text { Park Development Center } \\
\text { (TusPark) }\end{array}$ & 1994 & Corresponding to Type C \\
\hline $\begin{array}{l}\text { Type } 5 \text { University-owned } \\
\text { enterprises }\end{array}$ & Tsinghua Holdings Co., Ltd & $2003 \sim$ & Corresponding to Type C \\
\hline $\begin{array}{l}\text { Type } 6 \text { National } \\
\text { Engineering Research Centers }\end{array}$ & $\begin{array}{l}\text { National CIMS Engineering } \\
\text { Research Center (CISM) }\end{array}$ & 1994 & Close to Type D \\
\hline $\begin{array}{l}\text { Type } 7 \text { University-region joint } \\
\text { research institutes }\end{array}$ & $\begin{array}{l}\text { The Research Institute of } \\
\text { Tsinghua University in Beijing }\end{array}$ & 1990s & Close to Type C \\
\hline $\begin{array}{l}\text { Type } 8 \text { University-enterprise joint } \\
\text { research centers }\end{array}$ & $\begin{array}{l}\text { Tsinghua-BP Clean Energy } \\
\text { Research and Education } \\
\text { Center }\end{array}$ & 2003 & Close to Type A \\
\hline
\end{tabular}

Table 10 Models and organizational characteristics of UTTOs at Tsinghua University

\begin{tabular}{|c|c|c|c|c|c|c|c|c|c|}
\hline $\begin{array}{l}\text { Types/ } \\
\text { Organizational Characteristic }\end{array}$ & & $\begin{array}{l}\text { Type } \\
1 \\
\text { OTTOs }\end{array}$ & $\begin{array}{l}\text { Type } \\
2 \\
\text { RTTOs }\end{array}$ & $\begin{array}{l}\text { Type } \\
3 \\
\text { UREs }\end{array}$ & $\begin{array}{l}\text { Type } \\
4 \\
\text { USPs }\end{array}$ & $\begin{array}{l}\text { Type } \\
5 \\
\text { UOES }\end{array}$ & $\begin{array}{l}\text { Type } \\
6 \\
\text { NERCs }\end{array}$ & $\begin{array}{l}\text { Type } \\
7 \\
\text { URJRI }\end{array}$ & $\begin{array}{l}\text { Type } \\
8 \\
\text { UEJRC }\end{array}$ \\
\hline \multirow[t]{2}{*}{$\begin{array}{l}\text { 1.Degree of disciplinary } \\
\text { specialization }\end{array}$} & $\begin{array}{l}\text { Discipline } \\
\text { integrated }\end{array}$ & $x$ & $x$ & & $x$ & $x$ & & $x$ & \\
\hline & $\begin{array}{l}\text { Discipline } \\
\text { specialized }\end{array}$ & & & $x$ & & & $x$ & & $x$ \\
\hline \multirow[t]{3}{*}{ 2.Degree of task specialization } & Fully integrated & & $x$ & & $x$ & & $x$ & $x$ & \\
\hline & $\begin{array}{l}\text { Backward } \\
\text { integrated }\end{array}$ & $x$ & & & & & & & $x$ \\
\hline & $\begin{array}{l}\text { Forward } \\
\text { integrated }\end{array}$ & & & $x$ & & $x$ & & & \\
\hline \multirow[t]{3}{*}{ 3. Level of autonomy } & Dependent & & $x$ & $x$ & & & $x$ & & $x$ \\
\hline & Semi-dependent & & & & $x$ & $x$ & & $x$ & \\
\hline & Independent & $x$ & & & & & & & \\
\hline \multirow[t]{2}{*}{ 4.Degree of exclusivity } & Exclusive & $x$ & $x$ & $x$ & & $x$ & $x$ & & $x$ \\
\hline & Non-exclusive & & & & $x$ & & & $x$ & \\
\hline \multirow[t]{2}{*}{ 5.Professionalization } & High level & & $x$ & & $x$ & $x$ & & $x$ & \\
\hline & Low level & $x$ & & $x$ & & & $x$ & & $x$ \\
\hline \multirow[t]{2}{*}{ 6.Standardization } & High level & $x$ & $x$ & & $x$ & $x$ & $x$ & $x$ & $x$ \\
\hline & Low Level & & & $x$ & & & & & \\
\hline
\end{tabular}

$\mathrm{X}$ : indicates that the type of university technology transfer organizations has the organizational characteristics on the left side of the column 
almost all university technology transfer organizations in Tsinghua University are required to report to the upper-level administration for approval on various important issues. Although the Science and Technology Deverlopment Service Department (1983-1990) was aimed to become independent entity for university-industry technology transfer but had to be integrated into the University's administration, due to system obstacles.

Second, university-run enterprises seem to be a decidedly unique kind of UTTOs in Tsinghua University in the Chinese context. During the periods of the end of 1980s and early 1990s, they became effective approaches to commercializing knowledge and technology produced by universities in China. Due to the weak absorptive capacity of firms, lack of IP protection, and high transaction costs in university-industry technology transfer, universities found it safe and practical to integrate the value chain of the research, development, and commercialization stages into one organizational entity. Establishing enterprises by universities themselves can avoid a long and complicated negotiating process with other enterprises (Kroll and Liefner 2008; Eun et al. 2006).

Third, the observation of Schoen et al. (2014) on some drawbacks of discipline-specialized university technology transfer organizations may not be visibly reflected in the Chinese context. For instance, Schoen et al. (2014) find that in the European context, the discipline specialization structure is not compatible with a dependent university technology transfer organization. "The inefficiencies due to lower economies of scale and less synergy exploitation observed in a discipline-specialized structure are perceived as too strong to be compensated by a single university" (p.443). Therefore, they suggest that the university should rather not form a discipline-specialized university technology transfer organization within the university administration. However, in China, many universities including Tsinghua University, established National Engineering Research Centers as highly discipline-specialized university technology transfer organizations. The establishment of National Engineering Research Centers is the government's top-down initiative with the primary aim of strengthening technology development in certain priority fields for the country. For those National Engineering Research Centers affiliated to Chinese research universities, they are dependent on the research resources of related disciplines of the universities. The combination of dependent relation with the host university and a discipline-specialized structure facilitates the knowledge generation and technology transfer process.

Fourth, in contrast to a tendency in Europe that the models of university technology transfer organizations become alike (Poglajen 2012), we find that university technology transfer organizations in China in the current stage are rather diversified. This may indicate that the development of university technology transfer organizations in Tsinghua University is still in its infancy and not yet a mature organizational field. It has been argued that early adoption of reforms is motivated by technical or economic needs, while the later organizational adaptation responds to the growing social legitimacy (Tolbert and Zucker 1983), which drives organizations to become similar explained by the isomophic mechanisms (DiMaggio and Powell, 1983). 


\section{Towards a typology of university transfer organizations in China}

After 40 years of development, currently, there are six types of university technology transfer organizations co-existing in Tsinghua University as follows:

1. Renewed technology transfer office: e.g, Science and Technology Development Department established in 1992, Scientific Research Institute since 2003, and Office of Technology Licensing as a spin-off of the Scientific Reserach Institute since 2015.

2. University-owned enterprise: e.g., Tsinghua Holdings Co., Ltd.

3. University science park: e.g., TusPark, entirelly owned subsidiary of Tus-Holdings Co., Ltd.

4. National Engineering Research Centers: e.g., National Computer Integrated Manufacturing System Engineering Research Center.

5. University-region joint research institutes: e.g., Research Institute of Industry Development of Tsinghua University, Beijing; Yangtze Delta Region Institute of Tsinghua University, Zhejiang; Institute of Tsinghua University, Hebei, Research Institute of Tsinghua University in Shenzhen, etc.

6. University-enterprise joint research centers: e.g., Tsinghua-Inter Jointly R\&D Center, Tsinghua-BP Clean Energy Research and Education Center, TsinghuaToshiba Energy and Environment Center, Tsinghua-Origin Water Company of the Environment Membrane Technology Center, etc.

Now, we try to establish a typology to group these organizations into four categories from the perspective of Triple Helix interactions bewteen university, industry and govenment (Etzkowitz 2008). The previous analysis implies that these university technology transfer organizations vary depending on their levels of connections with university, industry, and government. While by definition all the university technology transfer organizations must have organizational ties with their host university, our typology mainly distinguishes them by the extent to which the university technology transfer organizations are intertwined with or influenced by industry or government in terms of administration, funding, and institutional logics.

As such, there are two dimensions in our proposed typology. The first dimension is the level of influences by the government (low or high), and the second dimension is the level of influences by the industry (low or high). The typology is illustrated in Table 11, in which four models of university technology transfer organizations are identified namely, (I) University Administration Model, (II) Government-Driven Model, (III) Industry-Driven Model, and (IV) Triple Helix-Oriented Model. In the typology, the six existing university theology transfer organizations in Tsinghua University are allocated.

The renewed technology transfer offices are part of the admistration of Tsinghua University, in spite of their close collaboration with the industry. The offices are fully funded by the University, and their operation is subject to the logics of university administration.

The Government-Driven Model includes both National Engineering Centers and university-region joint research institutes. Both types of organizations are initiated because of the priorities and interests of either national or regional government. They are 
respectively funded by national or regional government. To some extent, the university-region joint research institutions play the role as an incubator for the technology transfer in the regions concerned. When it comes to operation, both types of organizations are primarily subject to the logics of public service institutions.

In the Industry-Driven model, there are university-owned enterprise and university-enterprise joint research centers. The former is an enterprise following the corporate logics. Although the latter is often in the form of enterprise with researchers from Tsinghua University, it is primarily funded by the partner enterprise and the activities are mainly around the enterprise's needs in the market, following the corporate logics. Thus, we consider the type of university-enterprise joint research centers Industry Driven.

Compared to other types of university technology transfer organizations, TusPark is unique in that it is subject to the triple influences of university, industry, and government. It is influenced by the university because TusPark is the extension of Tsinghua University's societal services. It offers space and services for commercialization of research output of the University, incubates start-ups, provides research and development for enterprises, and cultivates entrepreneurial and innovative talents. It is influenced by the industry because TusPark is operated and managed by TusPark Management Co., Ltd., which is the subsidiary company of Tus-Holdings Co., Ltd, a member of the Tsinghua Holdings Co., Ltd. It is influenced by the government, because the TusPark was approved by the Ministry of Science and Technology and Ministry of Education as one of the first patch of key university technology parks in 1993, enjoying preferential policies for relevant national development zones granted by the State.

\section{Relations between six co-existing university technology transfer organizations at Tsinghua University}

The different types of university technology transfer organizations do not operate in isolation. They collaborate with or supplement each other. The relations between the six existing university technology transfer organizations can be illustrated in Fig. 4.

Among all these university-industry technology transfer organizations, the role of Office of Technology Licensing (became relatively independent from the Scientific Research Institute in 2015) is most crucial. The Office of Technology Licensing is responsible for registration of all the scientific and technological achievements in Tsinghua University, including the National Engineering Research Centers. When some academics or research teams of the University have plans for technology transfer, the

Table 11 Typology of university technology transfer organizations at Tsinghua University

\begin{tabular}{|c|c|c|c|}
\hline & & \multicolumn{2}{|l|}{ Level of influences by the government } \\
\hline & & Low & High \\
\hline \multirow[t]{2}{*}{$\begin{array}{l}\text { Level of influences by the } \\
\text { industry }\end{array}$} & Low & $\begin{array}{l}\text { I: University Administration } \\
\text { Renewed technology transfer offices }\end{array}$ & $\begin{array}{l}\text { II: Government Driven } \\
\text { National Engineering Centers } \\
\text { University-region joint research } \\
\text { institutes }\end{array}$ \\
\hline & High & $\begin{array}{l}\text { III: Industry Driven } \\
\text { University-owned enterprises } \\
\text { University-enterprise joint research } \\
\text { centers }\end{array}$ & $\begin{array}{l}\text { IV: Triple Helix Oriented } \\
\text { Science parks }\end{array}$ \\
\hline
\end{tabular}


Office of Technology Licensing will make an evaluation about the commercial potential of the technologies and even help invite investors to support the most promising projects. Usually, the investors are Tsinghua Holdings Co., Ltd. and its member corporations. Those university-region joint research institutions may also become independent investors for realizing the commercial value of certain technologies. If the innovators or technology holders intend to start up an enterprise based on advanced scientific outputs, TusPark could be an ideal platform for its earlier growth, where they will get sustainable input of technology, capital, office spaces, and the other business operation services.

Besides inviting investors for commercializing technologies, the Office of Technology Licensing also serves as the interface of Tsinghua University to negotiate with potential partners, such as regional governments as well as domestic and international enterprises to establish various joint entities, such as university-regional joint research institutes and university-enterprise joint research centers. The joint institutes may result in spin-off enterprises. Some of those spin-offs are incubated in the TusPark and with the investment from the Tsinghua Holdings. For university-enterprise joint research centers, since their research outputs are primarily to meet the demands of the cooperating enterprises, few spin-offs come out. Therefore, this type of organizations has less interactions with other forms of university technology transfer organizations.

The Office of Technology Licensing assists the calculations of equity distribution in start-ups between the innovators and investing companies. The Office of Technology licensing also appoints some of its own staff to be senior managers of the Tsinghua Holdings and university region joint research institutions. For the Office itself, a Vice President of Tsinghua University is in charge of its operation.

From an technological innovation or invention developed by academics in the University to gaining benefits from the commercialization is a process of interlocking through different technology transfer organizations of Tsinghua University. First, an innovator or inventor will disclose his or her invention, together with the invention's commerrcial prospects, to the Office of Technology Licensing. Then, the staff from the

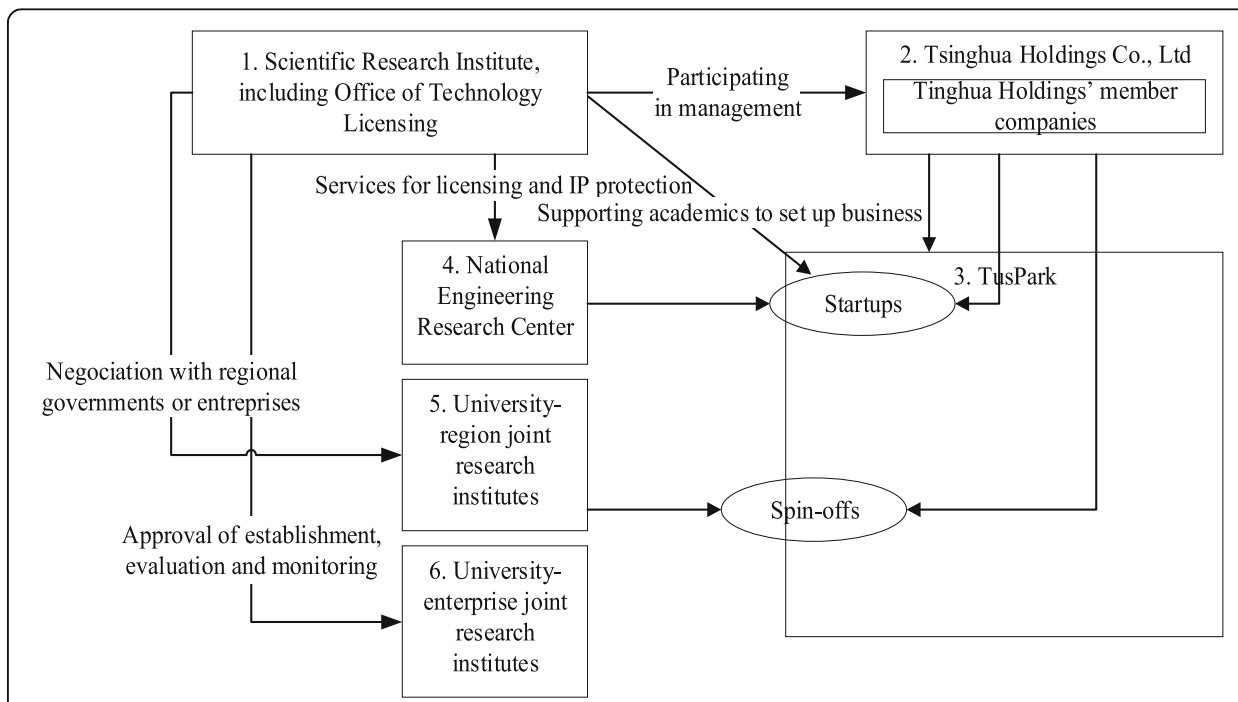

Fig. 4 Relations between six co-existing university technology transfer organizations in Tsinghua University 
Office will evaluate the market value of the invention. If the evaluation turns out to be positive, they will propose a specific plan of technology transfer in agreement witht the inventor among the four options, namely technology and patent licensing, technology assignment, using technology as shares for setting up a company, and seeking technology users in the market. In the case that the technology transfer will be through developing a start-up, the Tsinghua Holding Corporation will make inviestment and hold the shares on behalf of Tsinghua University. According to the regulations of Tsinghua University, the University (represented by Tsingbhua Holding Corpoation), the inventor's Faculty and the inventor respectively take the shares of $15 \%, 15 \%$, and $75 \%$. TusPark can help those high-tech start-ups at its initial stage with comprehensive technology transfer services. The inventions from the National Engineering Research Center usually take the first two options of technology transfer, but once a start-up will be developed around certain technoogy, the case will be furtehr processed by the Tsinghua Holdings Co., Ltd. and TusPark. It is the same logics with University-region joint research institutes and University-enterprises joint research centres, when it comes to technology transfer. In any case, an intellectual property management and leadership team group will be set up by the university to be in charge of the whole technology transfer process.

\section{Conclusions}

Our study for the first time identifies eight types of university technology transfer organizations in Tsinghua University developed since the 1980s and provides detailed descriptions of each model's organizational features. We further re-group the university technology transfer organizations into a typology. As the technology transfer at Tsinghua University can be seen as a microcosm of the field in China, our findings may largely help understand technology transfer organizations in other universities in China.

When examining the university technology transfer organizations in Tsinghua University, we developed an analytical framework by synthesizing useful insights from the international literature. When discovering some unique features of the Chinese university technology transfer organizations, our empirical analysis has also approved the usefulness of the analytical framework in the Chinese context. Meanwhile, our enhanced six-dimension analytical framework may add value to the international literature, because the revised framework is grounded in both eastern and western contexts, thus having much potential to be used for cross-country comparison of university technology transfer organizations.

Although the paper focuses on the development of a typology of university technology transfer organizations, the analysis of their organizational characteristics also provides some practical implications for different stakeholders. First, it provides a solid basis for Chinese policymakers to consider what optimal models of university technology transfer organizations are. Although several forms of university technology transfer organizations co-exist in China, the tendency is that they become more independent, have more professional management, and take more financial accountability. Thus, when planning future development of university technology transfer organizations, it may be worthwhile to retain these features. While there may be several scenarios for future university technology transfer 
organizations, we envision that one option is to develop some kind of more professional university technology transfer organization which is no longer an administrative organization like the current technology transfer offices in universities, but primarily provides fully integrated services for technology transfer and operates according to market mechanisms.

Second, with a better understanding of the types and characteristics of university technology transfer organizations, the university-industry technology transfer managers are likely to adjust their managerial strategies and practices to better fit the developmental needs in contingent situations. Our proposition is that university technology transfer organizations would be more productive when having more autonomy and being supported by a professional team.

Third, the study has potential to assist international actors to better collaborate with China in technology transfer and innovation. By using an analytical framework based on international experience, the university technology transfer organization types and associated activities described here are likely to be more transparent and understandable to international actors. Recently, increasing numbers of multi-national corporations have tended to cooperate with Chinese research universities in $R \& D$ and technology transfer (Ma 2015). The understanding of different university technology transfer organizations in China may facilitate these international actors' operations in China. Specifically, it may help them to strategically plan where to enter the Chinese technology transfer systems if they want to collaborate with local research universities and adapt their R\&D approaches to be more compatible with Chinese practices.

\title{
Additional file
}

Additional file 1: Translation of the abstract into Arabic. (PDF $51 \mathrm{~kb}$ )

\begin{abstract}
Abbreviations
IP: Intellectual property; NERCs: National Engineering Research Centers; OTTO: Original technology transfer office; R\&D: Research and development; RTTO: Renewed technology transfer office; S\&T: Science and technology;

UEJRC: University-enterprise joint research centers; UOEs: University-owned enterprises; UREs: University-run enterprises; URJRI: University-region joint research institutes; USPS: University science parks
\end{abstract}

\section{Acknowledgements}

Han Zhang thanks Xianfei Meng, the vice director of The Office of Technology Licensing, Tsinghua University, who helped to contact the interviews.

\section{Funding}

"Yangfan Scholarship" (JGWXJCYF201615) from the Beijing Municipal Education Working Commission. Foundation for Humanities and Social Sciences from the Ministry of Education of China (Grant number:18YJC630239)

\section{Availability of data and materials}

Not applicable

Authors' contributions

$\mathrm{HZ}$ conducted the interviews and data analysis with primary contribution of identifying eight types of university technology transfer organisations at Tsinghua University. YC framed the general structure and analytical framework, and made primary contribution to the Discussions. FL helped design the outline of interview and data collection. All authors read and approved the final manuscript.

Authors' information

Han Zhang is an assistant professor of the School of Marxism, Communication University of China.

Yuzhuo Cai is a university lecturer and adjunct professor of the School of Management, University of Tampere.

Lizheng Feng is a professor and the Vice Dean of the School of Social Sciences, Tsinghua University. 


\section{Consent for publication}

All of the authors in this paper agree for publication.

\section{Competing interests}

The authors declare that they have no competing interests. Social Sciences from the Ministry of Education of China (Grant number:18YJC630239).

\section{Publisher's Note}

Springer Nature remains neutral with regard to jurisdictional claims in published maps and institutional affiliations.

\section{Author details}

${ }^{1}$ School of Marxism, Communication University of China, Beijing, China. ${ }^{2}$ School of Management, University of

Tampere, Tampere, Finland. ${ }^{3}$ School of Social Sciences, Tsinghua University, Beijing, China.

Received: 18 June 2018 Accepted: 12 November 2018

Published online: 24 December 2018

\section{References}

Bercovitz J, Feldman M, Feller I, Burton R (2001) Organizational structure as a determinant of academic patent and licensing behavior: an exploratory study of Duke, Johns Hopkins, and Pennsylvania State Universities. J Technol Transf 26(1):21-35. https://doi.org/10.1023/a:1007828026904.

Brescia F, Colombo G, Landoni P (2016) Organizational structures of Knowledge Transfer Offices: an analysis of the world's top-ranked universities. J Technol Transf 41(1):132-151. https://doi.org/10.1007/s10961-014-9384-5.

Cai Y (2004) Confronting the global and the local--a case study of Chinese higher education. Tert Educ Manag 10(2):157-169.

Cai Y (2014) Implementing the Triple Helix model in a non-Western context: an institutional logics perspective. Triple Helix 1(1):1-20. https://doi.org/10.1186/s40604-014-0001-2.

Cai Y (2015) What contextual factors shape "innovation in innovation"? -integration of insights of the Triple Helix and the institutional logics perspective. Soc Sci Inf 54(3):299-326. https://doi.org/10.1177/0539018415583527.

Cai $Y$ (2017) From an analytical framework for understanding the innovation process in higher education to an emerging research field of innovations in higher education. Rev High Educ 40(4):585-616. https://doi.org/10.1353/rhe.2017.0023.

Cai Y (2018) University's Regional Engagement in China. In: Peters MA (ed) Encyclopedia of Educational Philosophy and Theory. Springer Singapore, Singapore, pp 1-7. https://doi.org/10.1007/978-981-287-532-7_603-2.

Cai Y, Liu C (2015) The roles of universities in fostering knowledge-intensive clusters in Chinese regional innovation systems. Sci Public Policy 42(1):15-29. https://doi.org/10.1093/scipol/scu018.

Cai Y, Yan F (2017) Higher Education and University. In: Morgan WJ, Gu Q, Li F (eds) Handbook of Chinese Education. Edward Elgar, pp 169-193.

Cai Y, Zhang H, Pinheiro R (2015) Institutionalization of technology transfer organisations in Chinese universities. Eur J High Educ 5(3):297-315. https://doi.org/10.1080/21568235.2015.1044548.

Cesaroni F, Piccaluga A (2015) The activities of university knowledge transfer offices: towards the third mission in Italy. J Technol Transf: 44(4), 753-777. https://doi.org/10.1007/s10961-015-9401-3.

Chandler A (1962) Strategy and structure: chapters in history of the American industiral enterprise. The M.I.T. Press, Cambridge.

Chen K, Kenney M (2007) Universities/research institutes and regional innovation systems: the cases of Beijing and Shenzhen. World Dev 35(6):1056-1074.

Dai Y, Xue L (2011) University technology transfer and commercialization in China: using Tsinghua University as a case. In Wong PK (ed) Academic Entrepreneurship in Asia: The role and impact of universities in national innovation systems. Edward Elgar, Cheltenham, pp 223-253.

DiMaggio PJ, Powell W (1983) The iron cage revisited: institutional isomorphism and collective rationality. Am Sociol Rev 42 : 147-160

Drucker PF (1973) Management: tasks, responsibilities, practices. Claremont Harper \& Row, California.

Etzkowitz H (2008) The triple helix: university-industry-government innovation in action. Routledge, New York.

Eun J-H, Lee K, Wu G (2006) Explaining the "university-run enterprises" in China: a theoretical framework for universityindustry relationship in developing countries and its application to China. Res Policy 35(9):1329-1346. https://doi.org/10. 1016/j.respol.2006.05.008.

Franzoni C (2007) Opportunity recognition in technology transfer organizations. Int Entrep Manag J 3(1):51-67.

Friedman J, Silberman J (2003) University technology transfer: do incentives, management, and location matter? J Technol Transf 28(1):17-30. https://doi.org/10.1023/A:1021674618658.

Geuna A, Muscio A (2009) The governance of university knowledge transfer: a critical review of the literature. Minerva 47(1): 93-114. https://doi.org/10.1007/s11024-009-9118-2.

Heinzl J, Kor A-L, Orange G, Kaufmann H (2013) Technology transfer model for Austrian higher education institutions. J Technol Transf 38(5):607-640. https://doi.org/10.1007/s10961-012-9258-7.

Hong W (2008) Decline of the center: the decentralizing process of knowledge transfer of Chinese universities from 1985 to 2004. Res Policy 37(4):580-595. https://doi.org/10.1016/j.respol.2007.12.008.

Huang Y, Audretsch D, Hewitt M (2013) Chinese technology transfer policy: the case of the national independent innovation demonstration zone of East Lake. J Technol Transf 38(6):828-835. https://doi.org/10.1007/s10961-012-9292-5.

Kalar B, Antoncic B (2015) The entrepreneurial university, academic activities and technology and knowledge transfer in four European countries. Technovation 36-37:1-11. https://doi.org/10.1016/j.technovation.2014.11.002.

Kroll H, Liefner I (2008) Spin-off enterprises as a means of technology commercialisation in a transforming economy--evidence from three universities in China. Technovation 28(5):298-313. https://doi.org/10.1016/j. technovation.2007.05.002. 
Lin M, Foley \& Lardner LLP (2011) China Bayh-Dole Act: a framework fundamental to achieving the economic potential of China's National Patent Development Strategy (2011 - 2020). Foley \& Lardner LLP, 22 April.

Link AN, Siegel DS (2005) Generating science-based growth: an econometric analysis of the impact of organizational incentives on university-industry technology transfer. Eur J Financ 11(3):169-181. https://doi.org/10.1080/1351847042000254211.

Liu C, Cai Y (2018) Triple Helix model and institutional logics in Shenzhen special economic zone. Sci Public Policy 45(2):221231. https://doi.org/10.1093/scipol/scx059.

Liu H, Jiang Y (2001) Technology transfer from higher education institutions to industry in China: nature and implications. Technovation 21(3):175-188. https://doi.org/10.1016/S0166-4972(00)00045-6.

Ma J (2015) Internationalization of collaborative research units in Chinese flagship research universities: an academic perspective on cross-border Tiple Helix linkages. University of Hong Kong, Hong Kong.

Markman GD, Phan PH, Balkin DB, Gianiodis PT (2005) Entrepreneurship and university-based technology transfer. J Bus Ventur 20(2):241-263. https://doi.org/10.1016/j.jbusvent.2003.12.003.

Miesing P, Tang M, Li M (2014) University technology transfer in China. In: Corbett AC, Katz JA, Siegal DS (eds) Academic entrepreneurship: creating an entrepreneurial ecosystem (16 in advances in entrepreneurship, firm emergence and growth). Emerald Group Publishing Limited, pp 115-136.

Orcutt J, Shen H (2010) Shaping China's innovation future: university technology transfer in transition. Edward Elgar Publishing, Inc., UK.

Pfeffer J, Salancik GR (1978) The external control of organizations. Harper \& Row, New York.

Poglajen M (2012) University-industry knowledge and technology transfer: isomorphism of university technology transfer organizational units. The DRUID Society 2012 Conference, CBS, Copenhagen.

Schoen A, van Pottelsberghe de la Potterie B, Henkel J (2014) Governance typology of universities' technology transfer processes. J Technol Transf 39(3):435-453. https://doi.org/10.1007/s10961-012-9289-0.

Siegel DS, Waldman D, Link A (2003a) Assessing the impact of organizational practices on the relative productivity of university technology transfer offices: an exploratory study. Res Policy 32(1):27-48. https://doi.org/10.1016/S00487333(01)00196-2.

Siegel DS, Waldman DA, Atwater LE, Link AN (2003b) Commercial knowledge transfers from universities to firms: improving the effectiveness of university-industry collaboration. J High Technol Managem Res 14(1):111-133. https://doi.org/10. 1016/S1047-8310(03)00007-5

Tang M (2008) Complementary innovation systems for catching-up in China. In: EU-US early career researcher conference on research and innovation studies. University of Twente, Enschede, pp 1-4.

Tang M (2009) Technology transfer from university to industry: insight into university technology transfer in the Chinese national innovation system. Adonis \& Abbey Publishers Ltd, London.

Teng H (2010) University-industry technology transfer: framework and constraints. J Sustain Dev 3(2):296-300.

Tolbert PS, Zucker LG (1983) Institutional sources of change in the formal structure of organizations: the diffusion of civil service reform. Adm Sci Q 28(1):22-39.

Wang H, Zhou Y (2008) The evolving role of universities in the Chinese national innovation system. UniDev Discussion Paper Series Paper No.11. Research Policy Institute, Lund University, Lund.

Wang H, Zhou Y (2009) University-owned enterprises as entry point to the knowledge economy in China. Sci Public Policy 36:103-108.

Wang Y, Huang J, Chen Y, Pan X, Chen J (2013) Have Chinese universities embraced their third mission? New insight from a business perspective. Scientometrics 97(2):207-222. https://doi.org/10.1007/s11192-013-1055-z.

Weckowska DM (2015) Learning in university technology transfer offices: transactions-focused and relations-focused approaches to commercialization of academic research. Technovation 41-42:62-74. https://doi.org/10.1016/j. technovation.2014.11.003.

Williamson OE (1975) Markets and hierarchies: analysis and antitrust implications. The Free Press, New York.

Wright M, Birley S, Mosey S (2004) Entrepreneurship and university technology transfer. J Technol Transfer 29(3-4):235-246. https://doi.org/10.1023/B:JOTT.0000034121.02507.f3.

Wu W, Zhou Y (2012) The third mission stalled? Universities in China's technological progress. J Technol Transf 37(6):812-827. https://doi.org/10.1007/s10961-011-9233-8.

Xue $L$ (2003) The relationship between universities and market (in Chinese). In: Liu X, Wang D, Hu Z (eds) Research report on the Chinese development of science and technology. Economic Management Publishing House, Beijing, pp 16-29.

Xue $L$ (2006) Universities in China's National Innovation System. The UNESCO Forum on Higher Education, Research and Knowledge, Paris, pp 27-30.

Zhang H (2016) Case study of university technology transfer and the evolution of intellectual property in China. Economy \& Management Publishing House, Beijing.

Zou Y, Zhao W (2013) Anatomy of Tsinghua University Science Park in China: institutional evolution and assessment. J Technol Transf, 39(5), 663-674. https://doi.org/10.1007/s10961-013-9314-y. 